Graphical Abstract

Recent advances in photocatalytic conversion of carbon dioxide into fuels with water and/or hydrogen using solar energy and beyond Yasuo Izumi

Graphical abstract

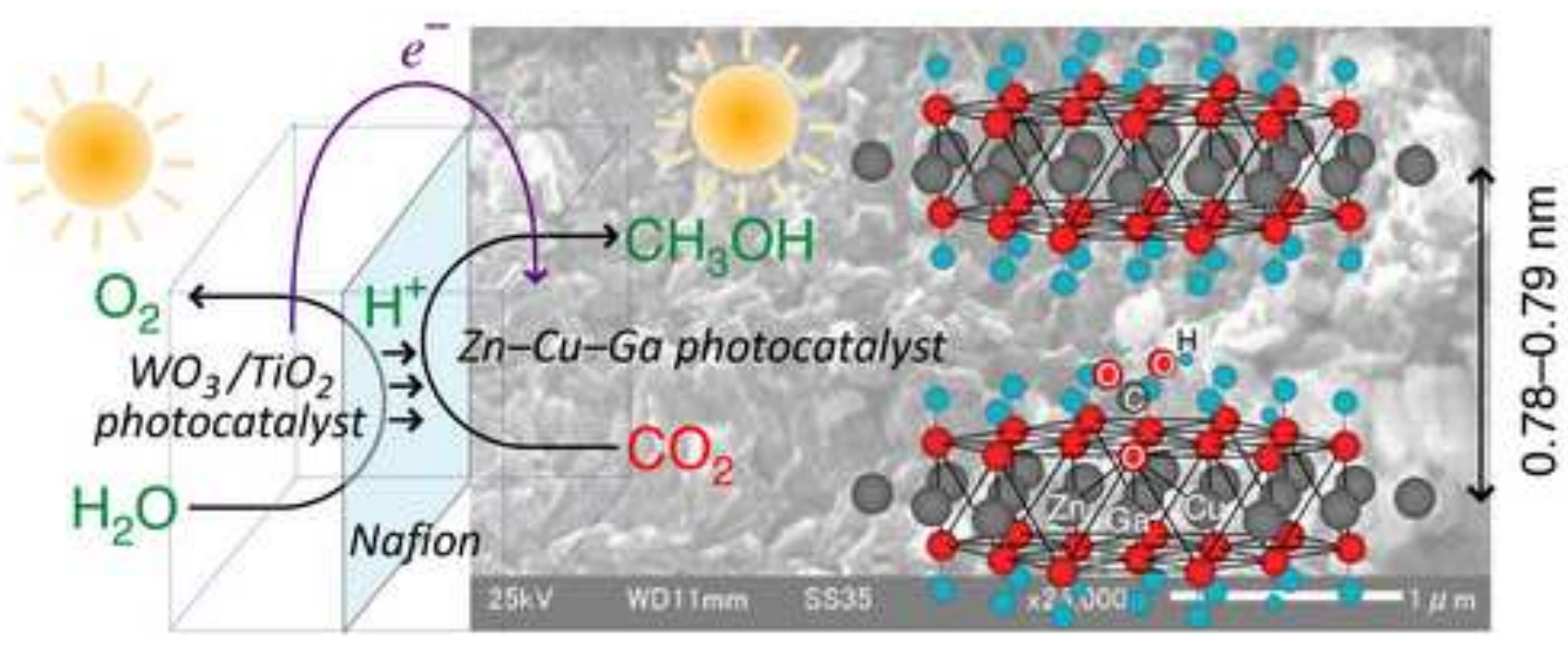




\title{
Recent advances in the photocatalytic conversion of carbon dioxide to fuels with water and/or hydrogen using solar energy and beyond
}

\author{
Yasuo Izumi $^{\mathrm{a}}$
}

${ }^{a}$ Department of Chemistry, Graduate School of Science, Chiba University, Yayoi 1-33, Inage-ku, Chiba 263-8522, Japan

Phone: +81 43290 3696, Fax: +81 432902783 .

E-mail address: yizumi@faculty.chiba-u.jp (Y. Izumi).

\section{Contents}

1. Background

2. Thermochemical conversion of $\mathrm{CO}_{2}$ to fuels

3. Photon energy conversion of $\mathrm{CO}_{2}$ to fuels with water

3.1. $\mathrm{TiO}_{2}$ photocatalysts

3.2. Metal-loaded $\mathrm{TiO}_{2}$ photocatalysts

3.3. Highly dispersed $\mathrm{TiO}_{2}$ photocatalysts

3.4. Modified/doped $\mathrm{TiO}_{2}$ photocatalysts

3.5. Historical low conversion rates and misunderstandings when using $\mathrm{TiO}_{2}$-based photocatalysts

3.6. Semiconductor photocatalysts other than $\mathrm{TiO}_{2}$

3.7. Carbon-based photocatalysts

4. Photon energy conversion of $\mathrm{CO}_{2}$ to fuels using hydrogen

4.1. Photocatalytic conversion of $\mathrm{CO}_{2}$ to methane or $\mathrm{CO}$ using hydrogen

4.2. Photocatalytic conversion of $\mathrm{CO}_{2}$ to methanol using hydrogen 
5. Photon energy conversion of $\mathrm{CO}_{2}$ to fuels using a new reaction system

5.1. Recycling of sacrificial electron donors

5.2. Photoconversion of $\mathrm{CO}_{2}$ to fuels utilizing anode oxidation and cathode reduction compartments

6. Concluding remarks

Acknowledgements

References

\section{ABSTRACT}

Photocatalytic reduction of carbon dioxide to fuels using solar energy is an attractive option for simultaneously capturing this major greenhouse gas and solving the shortage of sustainable energy. Efforts to demonstrate the photocatalytic reduction of $\mathrm{CO}_{2}$ are reviewed herein. Although the photocatalytic results depended on the reaction conditions, such as the incident/absorbing light intensity from the sun or a simulated solar light source, the performance of different systems is compared. When the reactants included $\mathrm{CO}_{2}$ and water, it was necessary to determine whether the products were derived from $\mathrm{CO}_{2}$ and not from impurities that accumulated on/in the catalysts as a result of washing, calcination, or pretreatment in a moist environment. Isotope labeling of ${ }^{13} \mathrm{CO}_{2}$ was effective for this evaluation using Fourier-transform infrared (FTIR) spectroscopy and mass spectrometry (MS). Comparisons are limited to reports in which the reaction route was verified spectroscopically, the $\mathrm{C}$ source was traced isotopically, or sufficient kinetic analyses were performed to verify the photocatalytic events. $\mathrm{TiO}_{2}$ photocatalytically produced methane at the rate of $\sim 0.1 \mu \mathrm{mol} \mathrm{h} \mathrm{h}^{-1} \mathrm{~g}_{\text {cat }}{ }^{-1}$. In aqueous solutions, formic acid, formaldehyde, and methanol were also produced. When $\mathrm{TiO}_{2}$ was atomically dispersed in zeolites or ordered mesoporous $\mathrm{SiO}_{2}$ and doped with $\mathrm{Pt}, \mathrm{Cu}, \mathrm{N}, \mathrm{I}, \mathrm{CdSe}$, or $\mathrm{PbS}$, the methane and $\mathrm{CO}$ formation 
rates were greater, reaching $1-10 \mu \mathrm{mol} \mathrm{h}^{-1} \mathrm{~g}_{\mathrm{cat}}{ }^{-1}$. As for semiconductors other than $\mathrm{TiO}_{2}$, $\mathrm{CdS}, \mathrm{SiC}, \mathrm{InNbO}_{4}, \mathrm{HNb}_{3} \mathrm{O}_{8}, \mathrm{Bi}_{2} \mathrm{WO}_{6}$, promoted $\mathrm{NaNbO}_{3}$, and promoted $\mathrm{Zn}_{2} \mathrm{GeO}_{4}$ produced methane or methanol at rates of $1-10 \mu \mathrm{mol} \mathrm{h}{ }^{-1} \mathrm{~g}_{\mathrm{cat}}{ }^{-1}$, and promoted $\mathrm{A}^{\mathrm{II}} \mathrm{La}_{4} \mathrm{Ti}_{4} \mathrm{O}_{15}$ produced $\mathrm{CO}$ at a rate greater than $10 \mu \mathrm{mol} \mathrm{h} \mathrm{g}_{\mathrm{cat}}^{-1}$, in addition to the historically known $\mathrm{ZnO}$ and $\mathrm{GaP}$ (formaldehyde and methanol formation). The photocatalytic reduction of $\mathrm{CO}_{2}$ was also surveyed with hydrogen, because hydrogen can be obtained from water photosplitting by utilizing natural light. $\mathrm{CO}$ was formed at a rate of $\sim 1 \mu \mathrm{mol} \mathrm{h}{ }^{-1} \mathrm{~g}_{\text {cat }}{ }^{-1}$ using $\mathrm{TiO}_{2}, \mathrm{ZrO}_{2}, \mathrm{MgO}$, and $\mathrm{Ga}_{2} \mathrm{O}_{3}$, whereas both $\mathrm{CO}$ and methanol were formed at a rate of $0.1-1 \mu \mathrm{mol} \mathrm{h}{ }^{-1} \mathrm{~g}_{\mathrm{cat}}{ }^{-1}$ using layered-double hydroxides consisting of $\mathrm{Zn}, \mathrm{Cu}, \mathrm{Al}$, and $\mathrm{Ga}$. When hydrogen is used, in addition to identifying the origin of the carbon, it is critical to confirm that the products are photocatalytically formed, not thermally produced via $\mathrm{CO}_{2}$ hydrogenation. The feasibility of the strategy involving the recycling of a sacrificial electron donor and the direct supply of protons and electrons released from water oxidation catalysts to photocatalysts for the reduction of $\mathrm{CO}_{2}$ to fuels has been demonstrated. However, based on the results obtained to date, it is clear that the practical use of the photocatalytic reduction of $\mathrm{CO}_{2}$ as one possible solution for global warming and the world's energy problems requires the development of more efficient photocatalysts.

Keywords: Semiconductor photocatalyst, Solar energy, Carbon dioxide, Fuel, Artificial photosynthesis, Layered-double hydroxide 


\section{Background}

Owing to the limited amount of energy sources and the recent effects of fossil fuel use on the global environment, the paradigm of energy supply is changing from one based on the use of carbon-rich rocks, peat, and liquid found in the Earth to one based on renewable sources, such as energy crops, sunlight, and wind [1]. According to the Intergovernmental Panel on Climate Change (IPCC), oil (34.6\%), coal (28.4\%), gas $(22.1 \%)$, and nuclear energy $(2.0 \%)$ were major worldwide energy sources in 2008 (Figure 1). The percentage of renewable energy was $12.9 \%$; however, if the traditional simple burning of biomass $(6.3 \%)$ is excluded, renewable energy accounted for only $6.6 \%$ of total consumption.

Carbon dioxide is one of the major greenhouse gases and is formed as a result of the consumption of fossil fuels [2]. In the $\mathrm{CO}_{2}$ emission scenarios described for 2050, bioenergy $\left(1.6 \times 10^{20} \mathrm{~J} \mathrm{y}^{-1}\right)$, direct solar energy $\left(3 \times 10^{19} \mathrm{~J} \mathrm{y}^{-1}\right)$, and wind energy $\left(2.5 \times 10^{19} \mathrm{~J}\right.$ $\mathrm{y}^{-1}$ ) are the top three renewable technologies that must be adopted in order to realize the ambitious target that calls for the decrease in the atmospheric $\mathrm{CO}_{2}$ concentration to less than 440 ppm. Thus, renewable energy must be investigated intensively, because modern biomass, direct solar energy, and wind energy supply only $1.9 \times 10^{19}, 0.5 \times 10^{18}$, and $1 \times 10^{18}$ $\mathrm{J} \mathrm{y}^{-1}$, respectively [1], and the application of renewable energy is increasing very slowly.

Several methods for reducing the $\mathrm{CO}_{2}$ concentration in the atmosphere and preventing $\mathrm{CO}_{2}$ emissions due to human activity have been investigated, such as investigating the sorption of $\mathrm{CO}_{2}$ into new/functionalized materials; increasing the quantity of green carbon sinks (plants, phytoplankton, and algae containing chloroplasts); increasing the level of dissolved carbonate and its salts in sea water; or capturing $\mathrm{CO}_{2}$ and transferring it to the bottom of the sea in a supercritical state [3].

It would be advantageous to capture $\mathrm{CO}_{2}$ from the atmosphere or the exhaust of factories/power stations and convert it to fuel by using a sustainable source of energy such as 
sunlight. This option solves the problems of global warming and the sustainable energy shortage simultaneously [3-6]. It is an enormously difficult task to combine water splitting and carbon dioxide reduction $[3,7,8]$. Water oxidation and the subsequent reduction of $\mathrm{CO}_{2}$ are required. This review mainly discusses the photocatalytic conversion of $\mathrm{CO}_{2}$ to fuels (Sections 3, 4, and 5) using semiconductors, but also presents a comparison of the related thermochemical conversion of $\mathrm{CO}_{2}$ to fuels (Section 2) via the reduction-oxidation of metal oxides.

\section{Thermochemical conversion of $\mathrm{CO}_{2}$ to fuels}

The energy from the sun that reaches the Earth in one hour is 9,200 times $\left(4.3 \times 10^{20} \mathrm{~J}\right.$ $\left.\mathrm{h}^{-1}\right)$ the energy consumed on the Earth in one hour in $2001\left(4.7 \times 10^{16} \mathrm{~J} \mathrm{~h}^{-1}\right)$ [9]. In other words, all the energy consumed on the Earth in one year can be supplied from solar energy in only $1 \mathrm{~h}$. To utilize the enormous energy provided by the sun, two-step thermochemical cycles to dissociate $\mathrm{CO}_{2}$ and $\mathrm{H}_{2} \mathrm{O}$ using metal oxide redox reactions have been proposed [10]. Nonstoichiometric oxides such as cerium oxide are partially reduced at higher temperatures (1873 $\mathrm{K}$ for cerium oxide), releasing $\mathrm{O}_{2}$ under concentrated solar radiation, and then are oxidized again by reacting with $\mathrm{CO}_{2}$ and $\mathrm{H}_{2} \mathrm{O}$ at lower temperatures:

$$
\begin{gathered}
2 \mathrm{MO}_{2} \rightarrow 2 \mathrm{MO}_{2-\delta}+\delta \mathrm{O}_{2}(\mathrm{~g}) \\
\delta \mathrm{H}_{2} \mathrm{O}+\mathrm{MO}_{2-\delta} \rightarrow \delta \mathrm{H}_{2}(\mathrm{~g})+\mathrm{MO}_{2} \\
\delta \mathrm{CO}_{2}+\mathrm{MO}_{2-\delta} \rightarrow \delta \mathrm{CO}(\mathrm{g})+\mathrm{MO}_{2}
\end{gathered}
$$

where $\mathrm{M}$ is $\mathrm{Ce}, \mathrm{Zn}$, or $\mathrm{Fe}$, and the above stoichiometry represents an example for the case when $\mathrm{M}$ is $\mathrm{Ce}$.

Compared to the redox systems consisting of $\mathrm{Zn}^{\mathrm{II}} \mathrm{O}-\mathrm{Zn}^{0}$ and $\mathrm{Fe}^{\mathrm{II}} \mathrm{Fe}^{\mathrm{III}}{ }_{2} \mathrm{O}_{4}-\mathrm{Fe}^{\mathrm{II}} \mathrm{O}$, cerium oxide is attracting attention because $\mathrm{CeO}_{2}$ is partially reduced via the formation of an oxygen vacancy without significant reorganization of the crystal lattice, and therefore, it reversibly 
stores and releases lattice oxygen atoms. Furthermore, $\mathrm{CeO}_{2}$ has a high melting point (2220 $\mathrm{K})$, thermal stability, and is less susceptible to crystal-reordering phase transitions [11]. Above $1173 \mathrm{~K}$ under a solar flux with a density of $150 \mathrm{~W} \mathrm{~cm}^{-2}$, the average evolution rate of

$\mathrm{O}_{2}$ was $0.049 \mathrm{~mL} \mathrm{~min}^{-1} \mathrm{~g}_{\text {cat }}^{-1}$ from cerium oxide, and the obtained partially reduced $\mathrm{CeO}_{2-\delta}$ transformed $\mathrm{CO}_{2}$ to $\mathrm{CO}$ at $1173 \mathrm{~K}$ at an average rate of $1.8 \mathrm{~mL} \mathrm{~min}^{-1} \mathrm{~g}_{\mathrm{cat}}{ }^{-1}$ and transformed $\mathrm{H}_{2} \mathrm{O}$ to $\mathrm{H}_{2}$ at $1173 \mathrm{~K}$ at an average rate of $0.95 \mathrm{~mL} \mathrm{~min}^{-1} \mathrm{~g}_{\text {cat }}{ }^{-1}[10]$.

These thermochemical conversion rates are higher than the photocatalytic rates discussed below, but focusing lenses for sunlight and high-temperature reactors incur high initial investment costs.

\section{Photon energy conversion of $\mathrm{CO}_{2}$ to fuels with water}

\section{1. $\mathrm{TiO}_{2}$ photocatalysts}

The photon energy of sunlight can be converted to electric energy using solar cells [12] and to chemical energy using photocatalysts. The development of photocatalysts to convert solar energy to chemical energy is an indispensable option for storing energy and for mobile use, especially when using sustainable, cheaper semiconductors [3,5,9,13]. Photocatalytic conversions of $\mathrm{CO}_{2}$ to fuels with water using semiconductors are summarized in Table 1.

In a pioneering paper in 1979 , the photoreduction of $\mathrm{CO}_{2}$ to formaldehyde and methanol in purified water using the semiconductors $\mathrm{TiO}_{2}, \mathrm{ZnO}, \mathrm{CdS}, \mathrm{GaP}, \mathrm{SiC}$, and $\mathrm{WO}_{3}$ was reported [14]. Based on the correlation between the conduction band energy potential and the yield of methanol, it was suggested that the photoreduction of $\mathrm{CO}_{2}$ proceeded by the photoexcited electrons in the conduction band moved to $\mathrm{CO}_{2}$. The conduction band energy minimum was higher than that for $\mathrm{CO}_{2}$ photoreductions.

$$
\begin{gathered}
\mathrm{CO}_{3}{ }^{2-}+6 \mathrm{H}^{+}+4 e^{-} \rightarrow \mathrm{H}_{2} \mathrm{CO}(a q)+2 \mathrm{H}_{2} \mathrm{O}, E^{\circ}(298 \mathrm{~K})=+0.197 \mathrm{~V} \\
\mathrm{CO}_{3}{ }^{2-}+8 \mathrm{H}^{+}+6 e^{-} \rightarrow \mathrm{CH}_{3} \mathrm{OH}(a q)+2 \mathrm{H}_{2} \mathrm{O}, E^{\circ}(298 \mathrm{~K})=+0.209 \mathrm{~V}
\end{gathered}
$$


in which the electric potentials are referenced to a standard hydrogen electrode (SHE). The photocatalytic results in this review are explained on the basis of this band gap electron excitation mechanism.

The photoreduction of $\mathrm{CO}_{2}$ using $\mathrm{TiO}_{2}$ has been most extensively investigated (Table 1A). The $\mathrm{CO}_{2}$ photoreduction in water-saturated $\mathrm{CO}_{2}$ gas was compared at $111 \mathrm{kPa}$ using $\mathrm{TiO}_{2}$ powder (reference catalyst JRC-TIO-4, Catalysis Society of Japan), anchored Ti oxide on porous Vycor glass (PVG), and 4-mm pelletized $\mathrm{TiO}_{2}$ under UV (ultraviolet) light for $48 \mathrm{~h}$. The methane formation rates were $14 \mathrm{nmol} \mathrm{h}^{-1} \mathrm{~g}_{\text {cat }}{ }^{-1}, 2.5 \mathrm{nmol} \mathrm{h}^{-1} \mathrm{~g}_{\text {cat }}{ }^{-1}$, and $2.1 \mathrm{nmol} \mathrm{h}^{-1}$ $\mathrm{g}_{\mathrm{cat}}{ }^{-1}$, respectively [15], suggesting that the specific surface area of the catalyst was of prime importance. $\mathrm{CO}$ and $\mathrm{H}_{2}$ were minor products.

The photocatalytic performance was also compared on a single crystal surface of rutile-type $\mathrm{TiO}_{2}(100)$ ( $\mathrm{Ti}$ terminating) and $\mathrm{TiO}_{2}(110)$ (O terminating) (Figure 2). Careful kinetic measurements were performed, because the surface area of a single crystal surface is limited in comparison to that of porous powders. The $\mathrm{TiO}_{2}(100)$ surface was more photocatalytically active than the $\mathrm{TiO}_{2}(110)$ surface by a factor of 7.4 , suggesting that a reductive Ti-terminating surface is favorable for reducing $\mathrm{CO}_{2}[16]$.

The reactant $\mathrm{CO}_{2}$ was condensed to a supercritical $(\mathrm{sc})$ condition $\left(T_{\text {critical }}=304.1 \mathrm{~K}\right.$, $\left.P_{\text {critical }}=7.375 \mathrm{MPa}\right)[17]$ to boost the reaction frequency. When anatase-type $\mathrm{TiO}_{2}$ powder was set in supercritical $\mathrm{CO}_{2}(308 \mathrm{~K}, 9.0 \mathrm{MPa})$ and irradiated under $\mathrm{UV}$ visible light $(>340$ $\mathrm{nm}$ ) followed by the addition of water, formic acid was formed at a rate of $1.8 \mu \mathrm{mol} \mathrm{h}^{-1} \mathrm{gcat}^{-1}$ [18]. The two-step synthesis of formic acid starting from $\mathrm{CO}_{2}$ was accelerated by the addition of phosphoric, nitric, or hydrochloric acid in the second step. In particular, an $\mathrm{H}_{3} \mathrm{PO}_{4}$ solution worked best for protonation to form formic acid at a $\mathrm{pH}$ of 2.2 and a rate of $2.9 \mu \mathrm{mol} \mathrm{h}^{-1} \mathrm{~g}_{\text {cat }}{ }^{-1}$.

This result reported in reference 18 is one of the best rates in Table 1A for conditions where the photocatalytic reaction route was supported by spectroscopy. The reaction 
mechanism was proposed to proceed through a one-electron reduced radical intermediate species $\left(\cdot \mathrm{CO}_{2}^{-}\right)$whose presence was confirmed by electron spin resonance (ESR) measurements:

$$
\begin{gathered}
h v \\
\mathrm{TiO}_{2} \rightarrow e^{-}\left(\mathrm{as} \mathrm{Ti}^{3+}\right)+h^{+} \\
\mathrm{Ti}^{4+}-\mathrm{O}^{2-} \rightarrow \mathrm{Ti}^{3+}-\mathrm{O}^{-} \\
\mathrm{CO}_{2}+e^{-} \rightarrow \cdot \mathrm{CO}_{2}^{-} \\
\cdot \mathrm{CO}_{2}^{-}+2 \mathrm{H}^{+} \text {(of water or acid) }+e^{-} \rightarrow \mathrm{HCO}_{2} \mathrm{H} \\
\cdot \mathrm{CO}_{2}^{-}+\cdot \mathrm{CO}_{2}^{-}+2 \mathrm{H}^{+} \text {(of water or acid) } \rightarrow \mathrm{HCO}_{2} \mathrm{H}+\mathrm{CO}_{2}
\end{gathered}
$$

\subsection{Metal-loaded $\mathrm{TiO}_{2}$ photocatalysts}

Various studies on the use of an added metal to enhance the photocatalytic activity of $\mathrm{TiO}_{2}$ have also been reported. An aqueous suspension of $\mathrm{TiO}_{2}, \mathrm{Rh} / \mathrm{TiO}$, or $\mathrm{Rh} / \mathrm{WO}_{3}-\mathrm{TiO}_{2}$ at $333 \mathrm{~K}$ was bubbled with a $\mathrm{CO}_{2}$ flow and illuminated by a xenon lamp, and the exit gas was trapped at $273 \mathrm{~K}$ and analyzed [19]. The major product when using the $\mathrm{TiO}_{2}$ suspension was formaldehyde, which was formed at a rate of $2.0 \mu \mathrm{mol} \mathrm{h}{ }^{-1} \mathrm{~g}_{\text {cat }}{ }^{-1}$ (Table 1A). A minor amount of formic acid was also detected. However, the major product detected when using the air-calcined $\mathrm{Rh} / \mathrm{WO}_{3}-\mathrm{TiO}_{2}$ suspension was formic acid, which formed at a rate of 1.6 $\mu \mathrm{mol} \mathrm{h}{ }^{-1} \mathrm{~g}_{\mathrm{cat}}^{-1}$ (Table 1B). Minor amounts of methanol and formaldehyde were also detected. Furthermore, the product distribution clearly changed again when $\mathrm{H}_{2}$-reduced (473 $\mathrm{K}) \mathrm{Rh} / \mathrm{WO}_{3}-\mathrm{TiO}_{2}$ was used. In this case, methanol was synthesized exclusively at a rate greater than $4.0 \mu \mathrm{mol} \mathrm{h}^{-1} \mathrm{~g}_{\mathrm{cat}}{ }^{-1}$.

The following reaction mechanism, which again includes a one-electron reduced species $\left(\cdot \mathrm{CO}_{2}^{-}\right)$, was proposed [19] and is based on a probable photo-assisted thermal methanol synthesis at $333 \mathrm{~K}$, starting from $\mathrm{CO}_{2}$ and $\mathrm{H}_{2} \mathrm{O}$.

$$
\mathrm{CO}_{2}+e^{-} \rightarrow \cdot \mathrm{CO}_{2}^{-}
$$




$$
\begin{gathered}
\cdot \mathrm{CO}_{2}^{-}+\mathrm{H}_{2} \mathrm{O} \rightarrow \mathrm{HC}(\mathrm{O}) \mathrm{O} \cdot+\mathrm{OH}^{-} \\
\mathrm{HC}(\mathrm{O}) \mathrm{O} \cdot+e^{-} \rightarrow \mathrm{HCO}_{2}^{-} \\
\mathrm{HCO}_{2}^{-}+\mathrm{H}^{+} \rightarrow \mathrm{HCO}_{2} \mathrm{H}
\end{gathered}
$$

It is also plausible that water photosplitting first occurred photocatalytically, and then the thermal reaction of $\mathrm{CO}_{2}$ with $\mathrm{H}_{2}$ (or a $\mathrm{H}$ species present on the Rh surface) proceeded, because $\mathrm{Rh} / \mathrm{WO}_{3}-\mathrm{TiO}_{2}$ is a typical thermal catalyst for $\mathrm{CO} / \mathrm{CO}_{2}$ hydrogenation [20-24].

The addition of $\mathrm{Cu}^{+}$to $\mathrm{TiO}_{2}$ powder photocatalysts was reported to lead to the formation of methanol [16]. The effects of doped-d $\mathrm{d}^{10}$-configuration $\mathrm{Cu}^{+}, \mathrm{Ag}^{+}$, and $\mathrm{Pb}^{2+}$ ions on $\mathrm{d}^{0}$-configuration metals, such as $\mathrm{Ti}, \mathrm{Nb}$, and Ta oxides, have been discussed for photocatalytic water splitting reactions, and hopefully can be applied also to the carbon dioxide photoreduction [25].

CdSe quantum dots $(2.5$ and $6.0 \mathrm{~nm})$ were mixed with a $\mathrm{Pt} / \mathrm{TiO}_{2}$ photocatalyst, and the photocatalyst was sensitized for the photoreduction of $\mathrm{CO}_{2}(40 \mathrm{~Pa})$ with moisture $(400 \mathrm{~Pa})$ under visible light exposure [26]. The photoexcitation of the electrons between the band gap of $\mathrm{TiO}_{2}$ by visible light $(>420 \mathrm{~nm})$ is hardly possible, but the photoexcitation of electrons between the band gap of the CdSe quantum dots is possible using visible light, and the excited electrons would be injected to the conduction band of $\mathrm{TiO}_{2}$ (Figure 3). With this system, the conversion of $\mathrm{CO}_{2}$ to methane (major) and methanol (minor) was observed for $4-6 \mathrm{~h}$, but because of the oxidation of the CdSe quantum dots, the photocatalyst was deactivated. $\mathrm{PbS}$ quantum dots $(4 \mathrm{~nm})$ were also effective for boosting the photocatalytic conversion of $\mathrm{CO}_{2}$ to $\mathrm{CO}$ and methane (Table 1B) [27].

\subsection{Highly dispersed $\mathrm{TiO}_{2}$ photocatalysts}

The photocatalytic enhancement of $\mathrm{TiO}_{2}$ was also attempted using highly dispersed active $\mathrm{Ti}$ ion species. The performance of $\mathrm{Ti}$ species anchored on $\mathrm{PVG}$ prepared from $\mathrm{TiCl}_{4}$ and highly dispersed $\mathrm{TiO}_{2}$ powder in the photocatalytic reduction of $\mathrm{CO}_{2}$ was compared [16]. 
The Ti sites of Ti-PVG were surface-isolated tetrahedral $\mathrm{TiO}_{4}$ based on the intense $\mathrm{Ti} 1 \mathrm{~s}-3 \mathrm{~d}$ electronic transition peak and a weaker signal ascribed to $\mathrm{Ti}-\mathrm{O}-\mathrm{Ti}$ (or $\mathrm{Ti}-\mathrm{O}-\mathrm{Si}$ ) bonding in the Ti K-edge extended X-ray absorption fine structure (EXAFS) compared to highly dispersed anatase-type $\mathrm{TiO}_{2}$.

Under $\mathrm{CO}_{2}$ gas and water vapor, the photocatalysts were irradiated with UV light through water and a cut-off filter $(\lambda>280 \mathrm{~nm})$ at $323 \mathrm{~K}$. The anatase-type $\mathrm{TiO}_{2}$ exclusively produced methane with a formation rate of $0.17 \mu \mathrm{mol} \mathrm{h}^{-1} \mathrm{~g}_{\text {cat }}{ }^{-1}$, in contrast to the Ti-PVG, which led to the formation of methane, methanol, and CO. The methane formation rates for the Ti-PVG photocatalyst increased from $1.6 \mathrm{nmol} \mathrm{h}^{-1} \mathrm{~g}_{\text {cat }}{ }^{-1}$ to $5.0 \mathrm{nmol} \mathrm{h}^{-1} \mathrm{~g}_{\text {cat }}{ }^{-1}$ when the molar ratio of $\mathrm{H}_{2} \mathrm{O}$ and $\mathrm{CO}_{2}$ increased from 0 to 3 and then to increased to $20 \mathrm{nmol} \mathrm{h}^{-1} \mathrm{~g}_{\text {cat }}{ }^{-1}$ when the molar ratio of $\mathrm{H}_{2} \mathrm{O}$ and $\mathrm{CO}_{2}$ increased to 5 .

In addition, the total yield increased when this UV irradiation test was conducted at 323 $\mathrm{K}$ compared to that conducted at $275 \mathrm{~K}$. Based on the temperature dependence, the thermal assist mechanism may be applicable in reference 16 , but the charge separation between Ti and $\mathrm{O}$ in the $\mathrm{Ti}^{3+}-\mathrm{O}^{-}$bond was monitored by ESR spectroscopy, and the quenching of photoluminescence in the presence of $\mathrm{CO}_{2}$ was also shown. Essentially, the charge separation between $\mathrm{Ti}$ and $\mathrm{O}$ in the $\mathrm{Ti}^{3+}-\mathrm{O}^{-}$bond played both reductive and oxidative photocatalytic roles [16].

The photocatalytic reduction of $\mathrm{CO}_{2}(24 \mu \mathrm{mol}, 0.73 \mathrm{kPa})$ by atomically dispersed Ti sites in Y-zeolite and its derivatives in the presence of water $(120 \mu \mathrm{mol}, 3.7 \mathrm{kPa})$ using UV light from a high-pressure $\mathrm{Hg}$ lamp $(>280 \mathrm{~nm})$ at $328 \mathrm{~K}$ [28,29] was also reported. Atomically dispersed Ti sites in Y-zeolite prepared via an ion-exchange method produced both methane $\left(46 \mathrm{nmol} \mathrm{h}^{-1} \mathrm{~g}_{\mathrm{cat}}{ }^{-1}\right)$ and methanol $\left(31 \mathrm{nmol} \mathrm{h}^{-1} \mathrm{~g}_{\mathrm{cat}}{ }^{-1}\right)$, whereas a Pt-loaded ion-exchanged Ti-Y-zeolite selectively formed methane $\left(80 \mathrm{nmol} \mathrm{h}^{-1} \mathrm{~g}_{\text {cat }}{ }^{-1}\right)$. Impregnated Ti oxide species in Y-zeolite exclusively formed methane.

The selectivity difference was explained as follows. The Ti sites in the ion-exchanged 
Y-zeolite are atomically dispersed on the basis of X-ray absorption near-edge structure (XANES) and EXAFS analyses. The charge separation between $\mathrm{Ti}$ and $\mathrm{O}$ in the $\mathrm{Ti}^{3+}-\mathrm{O}^{-}$ bond was evaluated on the basis of the photoluminescence spectra. The lifetime of the excited $\mathrm{Ti}^{3+}-\mathrm{O}^{-}$was determined to be $54 \mu$ s, which is substantially higher than that for $\mathrm{TiO}_{2}$ powders (nanosecond order). Owing to quantum size effects, the dispersed $\mathrm{Ti}^{3+}$ sites were more negative, and accordingly exhibited a greater reducing potential for the $\mathrm{CO}_{2}$ substrate, enabling methanol formation based on the band-gap values given from the UV-visible spectra. The $E^{\circ}$ values were -0.32 and $-0.244 \mathrm{~V}$ for methanol and methane formation, respectively (Figure 3). $\mathrm{CO}$ seemed to be an intermediate for the reduction of $\mathrm{CO}_{2}$, but $\mathrm{H}_{2}$ was not an intermediate. The water could have been oxidized to $\mathrm{OH}$ and $\mathrm{H}^{+}$, and the Pt sites probably worked to suppress charge recombination [28].

Similarly, Ti-MCM-48 produced both methane $\left(7.5 \mu \mathrm{mol} \mathrm{h}{ }^{-1} \mathrm{~g}_{\text {cat }}{ }^{-1}\right)$ and methanol (3.1 $\mu \mathrm{mol} \mathrm{h}{ }^{-1} \mathrm{~g}_{\mathrm{cat}}{ }^{-1}$ ), while Pt-Ti-MCM-48 was the most active and selectively formed methane $\left(12 \mu \mathrm{mol} \mathrm{h}{ }^{-1} \mathrm{~g}_{\mathrm{cat}}{ }^{-1}\right)$ [29]. Ti-SBA-15 also produced methane and methanol with formation rates of 0.31 and $0.081 \mu \mathrm{mol} \mathrm{h}{ }^{-1} \mathrm{~g}_{\text {cat }}{ }^{-1}$, respectively (Table 1B) [30]. In contrast, when the Ti-SBA-15 was illuminated in humid helium to remove any $\mathrm{C}$ residues, the rates of photoreduction of $\mathrm{CO}_{2}$ to ethane, methane, and ethylene were quite small $(0.020-0.007 \mu \mathrm{mol}$ $\mathrm{h}^{-1} \mathrm{~g}_{\mathrm{cat}}^{-1}$ ) [31]. Minor carbonaceous impurities in the Ti-MCM-41 were detected by Fourier-transform infrared (FTIR) spectroscopy using isotopes [32]. Based on these results, it is possible that the $\mathrm{C}$ residues remaining from the original organic template compounds used in the syntheses of Y-zeolite, MCM-48, and SBA-15 were the (partial) source of the products reported in references $28-30$, but the very low Ti loading level in reference 31 may be related to the lower photocatalytic activity.

Exclusive formation of $\mathrm{CO}$ and $\mathrm{O}_{2}$ was reported for Ti-MCM-41 under $\mathrm{CO}_{2}$ and $\mathrm{H}_{2} \mathrm{O}$ [32]. The light intensity from a 266-nm pulsed Nd:Yag laser was varied between 80 and 160 $\mathrm{mW} \mathrm{cm}^{-2}$, and a proportional increase in $\mathrm{CO}$ production was observed, which indicated a 
single photon process accompanying the charge separation between $\mathrm{Ti}$ and $\mathrm{O}$ in the $\mathrm{Ti}^{3+}-\mathrm{O}^{-}$ bond. The difference in the major product (CO) compared to that formed in references 29-31 (methane) is due to the different light source: a UV-pulsed laser versus a Hg lamp.

\subsection{Modified/doped $\mathrm{TiO}_{2}$ photocatalysts}

Nitrogen-doped $\mathrm{TiO}_{2}$ nanotube arrays were synthesized by the anodization of Ti metal in an ethylene glycol aqueous solution $(2$ vol\%) with $0.3 \mathrm{M}$ ammonium fluoride as a the $\mathrm{N}$ source. The $\mathrm{Cu}$ - or Pt-loaded $\mathrm{N}$-doped $\mathrm{TiO}_{2}$ nanotube photocatalysts were set outside on a sunny summer day in Pennsylvania, USA under water-vapor-saturated $\mathrm{CO}_{2}$ (total pressure $<$ $108 \mathrm{kPa}$ ) for $2.5-3.5 \mathrm{~h}$ at $317 \mathrm{~K}$ (Figure 4) [13]. The major product using the $\mathrm{Cu}-$ and Pt-loaded N-doped $\mathrm{TiO}_{2}$ nanotubes was methane, which was produced at a rate of $4.4 \mu \mathrm{mol}$ $\mathrm{h}^{-1} \mathrm{~g}_{\mathrm{cat}}{ }^{-1}$ and $2.9 \mu \mathrm{mol} \mathrm{h}^{-1} \mathrm{~g}_{\mathrm{cat}}{ }^{-1}$, respectively, in addition to minor amounts of $\mathrm{CO}$, ethane, propane, butane, pentane, and hexane. The major advantages of using $\mathrm{N}$-doped $\mathrm{TiO}_{2}$ nanotubes for the $\mathrm{CO}_{2}$ photoreduction were considered to be (1) a minimum thickness of the $\mathrm{N}$-doped $\mathrm{TiO}_{2}$ nanotubes of $\sim 10 \mathrm{~nm}$ versus a hole diffusion length of $\sim 10 \mathrm{~nm}$ [33] and an electron diffusion length of $\sim 10 \mu \mathrm{m}$ in $\mathrm{TiO}_{2}$; [34] and (2) the electron trap at the $\mathrm{Cu}$ or Pt to donate electrons to $\mathrm{CO}_{2}$. A later paper on the $\mathrm{CO}_{2}$ photoreduction using $\mathrm{Pt}-\mathrm{TiO}_{2}$ nanotubes reported the exclusive formation of methane in addition to trace amounts of ethane [35]. Based on a comparison of the two studies, it is possible to conclude that (at least part of) the hydrocarbons produced in reference 13 originated from the tape used in the reactor.

When the fraction of sunlight with wavelengths shorter than $400 \mathrm{~nm}$ was removed, the photocatalytic activity of $\mathrm{CO}_{2}$ reduction was reduced to $3 \%$ of that under the entire solar spectrum. The control reaction in the dark (using the $\mathrm{Cu}$-loaded $\mathrm{N}$-doped $\mathrm{TiO}_{2}$ nanotubes) and in the absence of catalyst produced methane at rates of $0.13 \mu \mathrm{mol} \mathrm{h}^{-1} \mathrm{~g}_{\mathrm{cat}}{ }^{-1}$ and $0.10 \mu \mathrm{mol}$ $\mathrm{h}^{-1} \mathrm{~g}_{\text {cat }}{ }^{-1}$, respectively. The reaction mechanism operating in response to the UV light was proposed as follows [13]. 


$$
\begin{gathered}
\mathrm{H}_{2} \mathrm{O}+h^{+} \rightarrow \cdot \mathrm{OH}+\mathrm{H}^{+} \\
\mathrm{H}^{+}+e^{-} \rightarrow \cdot \mathrm{H} \\
\cdot \mathrm{H}+\cdot \mathrm{H} \rightarrow \mathrm{H}_{2} \\
2 \mathrm{CO}_{2}+4 e^{-} \rightarrow 2 \mathrm{CO}+\mathrm{O}_{2} \\
\mathrm{CO}+6 e^{-}+6 \mathrm{H}^{+} \rightarrow \mathrm{CH}_{4}+\mathrm{H}_{2} \mathrm{O}
\end{gathered}
$$

Iodine-doped $\mathrm{TiO}_{2}$ is known as a visible-light-responsive photocatalyst, typically for photooxidation [36]. Essentially, doped $\mathrm{I}^{-}$anions form impurity energy levels above the valence band of $\mathrm{TiO}_{2}$ and extend the availability of the visible light. This strategy was applied to the $\mathrm{CO}_{2}$ photoreduction in the gas phase. The $\mathrm{CO}$ formation rate $(2.4 \mu \mathrm{mol} \mathrm{h}$ $\mathrm{g}_{\mathrm{cat}}{ }^{-1}$; Table 1B) [37] is comparable to verified methane formation rates using other dispersed or doped $\mathrm{TiO}_{2}$ photocatalysts. Linear $\mathrm{O}_{2}$ formation was also monitored, but to further discuss the following proposed mechanism compared to competitive $\mathrm{H}_{2}$ formation, quantitative kinetic data are needed.

$$
\begin{gathered}
\mathrm{TiO}_{2} \rightarrow h^{+}+e^{-} \\
2 \mathrm{H}_{2} \mathrm{O}+4 h^{+} \rightarrow 4 \mathrm{H}^{+}+\mathrm{O}_{2} \\
\mathrm{CO}_{2}+2 \mathrm{H}^{+}+2 e^{-} \rightarrow \mathrm{CO}+\mathrm{H}_{2} \mathrm{O}
\end{gathered}
$$

To summarize chapters $3.2-3.4$, when $\mathrm{TiO}_{2}$ was atomically dispersed on zeolites or ordered mesoporous $\mathrm{SiO}_{2}$ or doped with $\mathrm{Pt}, \mathrm{Cu}, \mathrm{N}, \mathrm{I}, \mathrm{CdSe}$, or $\mathrm{PbS}$, photocatalytic methane or CO formation rates increased to $1-10 \mu \mathrm{mol} \mathrm{h}^{-1} \mathrm{~g}_{\text {cat }}{ }^{-1}$.

\subsection{Historical low conversion rates and misunderstandings when using $\mathrm{TiO}_{2}$-based} photocatalysts

The reaction routes for the $\mathrm{CO}_{2}$ reduction with water should be carefully checked to determine whether the carbon source was actually the $\mathrm{CO}_{2}$ reactant. The major obstacle for the reduction of $\mathrm{CO}_{2}$ is the thermodynamic limitation [3]: 


$$
\mathrm{CO}_{2}(g)+2 \mathrm{H}_{2} \mathrm{O}(g) \rightarrow \mathrm{CH}_{3} \mathrm{OH}(g)+1.5 \mathrm{O}_{2}(g), \Delta G_{\mathrm{r}}^{\circ}=+689 \mathrm{~kJ} \mathrm{~mol}^{-1}
$$

This significant up-hill free-energy change is due to the greater enthalpies for $\mathrm{CO}_{2}$ and $\mathrm{H}_{2} \mathrm{O}$. The free-energy change for water splitting is lesser by $34 \%$.

$$
2 \mathrm{H}_{2} \mathrm{O}(g) \rightarrow 2 \mathrm{H}_{2}(g)+\mathrm{O}_{2}(g), \Delta G_{\mathrm{r}}^{\circ}=+457.2 \mathrm{~kJ} \mathrm{~mol}^{-1}
$$

Therefore, in view of the free-energy change, the $\mathrm{CO}_{2}$ conversion is extremely unfavorable, and the reduction of impurity carbon to methanol could be misinterpreted as the reaction of $\mathrm{CO}_{2}[38,39]$

In one example, $\mathrm{TiO}_{2}$ was synthesized by a sol-gel route starting from titanium(IV) $n$-butoxide and polyethylene glycol (PEG) [38] or $n$-butanol plus acetic acid [40-43]. Methanol $\left(20 \mu \mathrm{mol} \mathrm{h}{ }^{-1} \mathrm{~g}_{\text {cat }}{ }^{-1}\right)[42,43]$ and formic acid formation $\left(150-98 \mu \mathrm{mol} \mathrm{h}^{-1} \mathrm{~g}_{\text {cat }}{ }^{-1}\right)$ $[40,41]$ were reported using a suspended, $\mathrm{Cu}$-loaded, sol-gel-derived $\mathrm{TiO}_{2}$ in $\mathrm{NaOH}$ solution saturated with $\mathrm{CO}_{2}$ under $\mathrm{UV}$ light from a mercury lamp $[42,43]$ or using $\mathrm{Co}{ }^{\mathrm{II}}$-phthalocyanine $(\mathrm{Pc}) / \mathrm{TiO}_{2}$ and $\mathrm{Zn}{ }^{\mathrm{II}}-\mathrm{Pc} / \mathrm{TiO}_{2}$ under a $\mathrm{W}$ halogen lamp $[40,41]$. In an aqueous solution saturated with $\mathrm{CO}_{2}$ using $\mathrm{Nd}^{\mathrm{III}} / \mathrm{TiO}_{2}$ under $\mathrm{UV}$ irradiation, the formation rate of methanol was as much as $23 \mu \mathrm{mol} \mathrm{h}^{-1} \mathrm{~g}_{\mathrm{cat}}{ }^{-1}$ [44]. The $\mathrm{TiO}_{2}$ powder used in this study was also prepared via a sol-gel route.

$\mathrm{TiO}_{2}$ has also been synthesized via a sol-gel route starting from Ti(IV) tetrachloride and hydrochloric acid, followed by the addition of ammonia until the $\mathrm{pH}$ reached 7 . Nanocomposites of $\mathrm{TiO}_{2}$ and multi-walled carbon nanotubes (MWCNTs) produced ethanol, formic acid, and methane with formation rates of 30, 19, and $12 \mu \mathrm{mol} \mathrm{h}^{-1} \mathrm{~g}_{\mathrm{cat}}{ }^{-1}$, respectively, (Table 1B) in $\mathrm{H}_{2} \mathrm{O}$ and $\mathrm{CO}_{2}$ (molar ratio 5:1) under a UV lamp (365 nm) for $5 \mathrm{~h} \mathrm{[45].} \mathrm{In} \mathrm{this}$ study, $\mathrm{TiO}_{2}\left(\mathrm{P} 25\right.$, Degussa) and $\mathrm{TiO}_{2}$ synthesized by a sol-gel method were also tested for the $\mathrm{CO}_{2}$ photoreduction. Unmodified $\mathrm{TiO}_{2}$ ( $\left.\mathrm{P} 25\right)$ produced ethanol, formic acid, and methane with formation rates of 1.0, 19, and $15 \mu \mathrm{mol} \mathrm{h}^{-1} \mathrm{~g}_{\text {cat }}{ }^{-1}$, respectively, and the sol-gel-derived $\mathrm{TiO}_{2}$ was even more active. These results were in contradiction to those reported in 
references 15 and 16 in which anatase-type (or anatase-type major) $\mathrm{TiO}_{2}$ produced only methane at rates of $0.014-0.17 \mu \mathrm{mol} \mathrm{h}^{-1} \mathrm{~g}_{\mathrm{cat}}^{-1}$ under similar reaction conditions (Table 1A).

To investigate the surface reaction mechanism starting from $\mathrm{CO}_{2}$ to fuels, the isotope distribution of adsorbed $\mathrm{CO}\left({ }^{12} \mathrm{CO}\right.$ at $2115 \mathrm{~cm}^{-1}$ and ${ }^{13} \mathrm{CO}$ at $\left.2069 \mathrm{~cm}^{-1}\right)$ over $\mathrm{Cu}^{\mathrm{I}} / \mathrm{TiO}_{2}$ was monitored using diffuse reflectance infrared Fourier-transform spectroscopy in ${ }^{13} \mathrm{CO}_{2}$ gas (Figure 5) [38]. Adsorbed ${ }^{12} \mathrm{CO}$ species were the primary products, indicating that a reverse disproportionation reaction of impurity carbon with $\mathrm{CO}_{2}$ proceeded to form $\mathrm{CO}$.

$$
\left.{ }^{12} \mathrm{C} \text { (impurity in/on catalyst }\right)+{ }^{13} \mathrm{CO}_{2} \rightarrow{ }^{12} \mathrm{CO}+{ }^{13} \mathrm{CO}
$$

If the carbon residues deposited/buried on the catalyst surface during the catalyst synthesis were involved in reactions with photocatalytically activated surface-adsorbed water via

$$
\mathrm{CO}+2 \mathrm{H}_{2} \mathrm{O} \rightarrow \mathrm{CH}_{3} \mathrm{OH}+\mathrm{O}_{2}, \Delta G_{\mathrm{r}}^{\circ}=+432 \mathrm{~kJ} \mathrm{~mol}^{-1}
$$

in which the free-energy change is lesser by $37 \%$ compared to the reduction of $\mathrm{CO}_{2}$ to methanol, the thermodynamic limitation can be partially compensated for by the impurity carbon.

Recently, based on detailed gas chromatography (GC) and GC-MS (Mass spectrometry) analyses, the $\mathrm{C}$ source was carefully investigated with respect to the production of $\mathrm{CO}$, methane, ethane, acetic acid, formic acid, and methanol from $\mathrm{CO}_{2}$ [34]. The tests were conducted in $\mathrm{CO}_{2}$-saturated water using $\mathrm{TiO}_{2}(\mathrm{P} 25)$ at $278 \mathrm{~K}$ under $\mathrm{UV}$-visible light $(>310$ $\mathrm{nm}$ ). Using as-received $\mathrm{TiO}_{2}$, methane was formed at a rate $150 \mathrm{nmol} \mathrm{h}^{-1} \mathrm{~g}_{\text {cat }}{ }^{-1}$, but the molar amount corresponded well to that of acetic acid desorbed by calcination at $623 \mathrm{~K}$. The reaction was not considered to be $\mathrm{CO}_{2}$ photoreduction, but the photo-Kolbe reaction [46]:

$$
\begin{gathered}
\mathrm{CH}_{3} \mathrm{CO}_{2} \mathrm{H}+h^{+} \rightarrow \cdot \mathrm{CH}_{3}+\mathrm{CO}_{2}+\mathrm{H}^{+} \\
\cdot \mathrm{CH}_{3}+\mathrm{CH}_{3} \mathrm{CO}_{2} \mathrm{H} \rightarrow \mathrm{CH}_{4}+\cdot \mathrm{CH}_{2} \mathrm{CO}_{2} \mathrm{H}
\end{gathered}
$$

After calcination at $623 \mathrm{~K}$ and further thorough washing of the $\mathrm{TiO}_{2}$ with deionized water, the reaction was repeated, and the organics were not detected; the actual $\mathrm{CO}$ and methane formation rates under $\mathrm{UV}$-visible light were 350 and $25 \mathrm{nmol} \mathrm{h}^{-1} \mathrm{~g}_{\mathrm{cat}}^{-1}$, respectively. 
Similarly, photochemically deposited $\mathrm{Pd}-\mathrm{TiO}_{2}$ was washed several times and set in $\mathrm{CO}_{2}$-saturated water under UV-visible light. Methane was the major product $\left(370 \mathrm{nmol} \mathrm{h}^{-1}\right.$

$\mathrm{g}_{\mathrm{cat}}{ }^{-1}$ ), and ethane and $\mathrm{CO}$ were formed in minor amounts. The methane source was tested using ${ }^{13} \mathrm{CO}_{2}$, and the GC-MS peak at $m / e=17$ confirmed the formation of ${ }^{13} \mathrm{CH}_{4}$ directly from ${ }^{13} \mathrm{CO}_{2}$ [39].

In summary, based on the studies presented in references 38 and 39, it is essential to verify the $\mathrm{C}$ source for the products reported in references $40-45$. The products were very likely derived from an alkyl group of the catalyst precursor compounds or the organic solvent.

\subsection{Semiconductor photocatalysts other than $\mathrm{TiO}_{2}$}

In the pioneering report in 1979 , the photoreduction of $\mathrm{CO}_{2}$ to formaldehyde and methanol in water was reported using $\mathrm{TiO}_{2}, \mathrm{ZnO}, \mathrm{CdS}, \mathrm{GaP}, \mathrm{SiC}$, and $\mathrm{WO}_{3}$ (Table $1 \mathrm{C}$ ). The rates of formaldehyde production were in the order:

$$
\mathrm{CdS}>\mathrm{ZnO} \sim \mathrm{TiO}_{2}>\mathrm{GaP} \sim \mathrm{SiC}
$$

However, the rates of methanol formation followed quite a different order [14]:

$$
\mathrm{SiC} \gg \mathrm{CdS} \sim \mathrm{GaP}>\mathrm{ZnO}>\mathrm{TiO}_{2}
$$

$\mathrm{CdS}$ nanoparticles were supported on montmorillonite, and the photoreduction of $\mathrm{CO}_{2}$ was tested in an alkaline solution under UV light (254 nm) [47]. Although water photosplitting proceeded predominantly $\left(\mathrm{H}_{2}\right.$ formation rate: $\left.8.7 \mu \mathrm{mol} \mathrm{h}^{-1} \mathrm{~g}_{\mathrm{cat}}{ }^{-1}\right)$, the secondary hydrogenation of $\mathrm{CO}_{2}$ was suggested with a formation rate of $0.93 \mu \mathrm{mol} \mathrm{h}{ }^{-1} \mathrm{gcat}^{-1} \cdot \mathrm{p}-\mathrm{SiC}$ powder and copper powder were dispersed in a potassium hydrogen carbonate solution saturated with $\mathrm{CO}_{2}$ at a $\mathrm{pH}$ of 5 at $313 \mathrm{~K}$. When the suspension was illuminated with UV light from a mercury lamp $\left(7 \mathrm{~mW} \mathrm{~cm}^{-2}\right.$ at $\left.365 \mathrm{~nm}\right)$, methane was the major product, which had a formation rate of $0.63 \mu \mathrm{mol} \mathrm{h} \mathrm{h}^{-1} \mathrm{~g}_{\mathrm{cat}}{ }^{-1}$, and ethylene and ethane were minor products [48]. The $\mathrm{Cu}$ site was suggested to be an acceptor of photogenerated electrons, but the $\mathrm{Cu}-\mathrm{p}-\mathrm{SiC}$ photocatalyst deactivated in $1-2 \mathrm{~h}$. 
$\mathrm{InTaO}_{4}$ that was previously synthesized by solid-state synthesis starting from $\operatorname{In}_{2} \mathrm{O}_{3}$ and $\mathrm{Ta}_{2} \mathrm{O}_{5}$ was impregnated with $0-1.0 \mathrm{wt} \% \mathrm{NiO}$ using an aqueous nickel nitrate solution [49], calcined at $623 \mathrm{~K}$, reduced at $773 \mathrm{~K}$, oxidized at $473 \mathrm{~K}$, and then used as a catalyst for the photcatalytic reduction of $\mathrm{CO}_{2}$. After the photocatalytic test in a $\mathrm{CO}_{2}$-saturated potassium bicarbonate solution was complete, the aqueous phase was analyzed, and methanol was formed at a maximum rate of $1.4 \mu \mathrm{mol} \mathrm{h}^{-1} \mathrm{~g}_{\text {cat }}{ }^{-1}$ using $\mathrm{NiO} / \mathrm{InTaO}_{4}$. Unfortunately, control reactions (in the dark, in the absence of catalyst, in the absence of $\mathrm{CO}_{2}$ and/or $\mathrm{KHCO}_{3}$ ) and other product information, including analysis of the gas phase were not reported. The $\mathrm{NiO} / \mathrm{InTaO}_{4}$ photocatalysts were also tested for the gas-phase $\mathrm{CO}_{2}$ reduction using a monolith reactor [50]. The major product was acetaldehyde, which was formed at a rate of $0.21 \mu \mathrm{mol}$ $\mathrm{h}^{-1} \mathrm{~g}_{\mathrm{cat}}{ }^{-1}$ (Table 1C), rather than minor methanol formation.

$\mathrm{InNbO}_{4}$ was synthesized by solid-state reactions and then tested for the $\mathrm{CO}_{2}$ photoreduction in $\mathrm{KHCO}_{3}$ solution [51]. Based on the control tests and the fact that the catalyst was prepared via a carbon-free synthetic method, the methanol formation, which occurred at a rate of $1.3 \mu \mathrm{mol} \mathrm{h}{ }^{-1} \mathrm{~g}_{\mathrm{cat}}{ }^{-1}$ under UV-visible light, should be photocatalytic. Hydrothermally synthesized $\mathrm{HNb}_{3} \mathrm{O}_{8}$ nanobelts and $\mathrm{Bi}_{2} \mathrm{WO}_{6}$ nanoplates also underwent the photoreduction of $\mathrm{CO}_{2}$ to methane with rates of 3.6 and $1.1 \mu \mathrm{mol} \mathrm{h}{ }^{-1} \mathrm{~g}_{\mathrm{cat}}{ }^{-1}$, respectively, (Table 1C) [52,53] which are comparable to $\mathrm{TiO}_{2}$-based photocatalysts. The [001] face of the nanoplates was suggested to be responsible. Pt-promoted perovskite $\mathrm{NaNbO}_{3}$ was reported to produce methane from $\mathrm{CO}_{2}+\mathrm{H}_{2} \mathrm{O}$ at a rate comparable to the levels of the other best semiconductor photocatalysts: $4.9 \mathrm{~mol} \mathrm{~h}^{-1} \mathrm{~g}_{\mathrm{cat}}{ }^{-1}$ [54].

$\mathrm{BiVO}_{4}$ was synthesized by a hydrothermal method starting from acidic bismuth nitrate and alkaline ammonium vanadate solutions [55]. Cetyltrimethyl ammonium (CTMA) bromide (to obtain monoclinic $\mathrm{BiVO}_{4}$ crystals) or PEG (to obtain tetragonal $\mathrm{BiVO}_{4}$ crystals) was added to both solutions, and the two solutions were mixed. The mixed solution was heated at $473 \mathrm{~K}$ in an autoclave under microwave irradiation. In the cooled water saturated 
with $\mathrm{CO}_{2}$ gas, the monoclinic $\mathrm{BiVO}_{4}$ was reported to produce ethanol with rates of 2000 and $110 \mu \mathrm{mol} \mathrm{h}^{-1} \mathrm{~g}_{\mathrm{cat}}{ }^{-1}$ under UV-visible and visible light, respectively.

A control reaction was performed in nitrogen gas instead of $\mathrm{CO}_{2}$, and no ethanol production was detected. However, this fact did not rule out the presence of carbon impurity intermediates derived from $\mathrm{CTMA}^{+}$cations. In the FTIR spectrum for the as-prepared monoclinic $\mathrm{BiVO}_{4}$, very weak peaks appear in the 3000-2900 $\mathrm{cm}^{-1}$ region [55], which are likely due to the presence of $\mathrm{C}-\mathrm{H}$ bonds derived from $\mathrm{CTMA}^{+}$or $\mathrm{PEG}$ used during the catalyst preparation.

Delafossite $\mathrm{CuGa}_{1-x} \mathrm{Fe}_{x} \mathrm{O}_{2}(x=0.15)$ was tested in an ambient pressure of $\mathrm{CO}_{2}$-saturated $\mathrm{H}_{2} \mathrm{O}$ under a Xe arc lamp. The formation rate of the major product $\mathrm{CO}$ was reported to the $19 \%$ of the corresponding rate to form methane obtained with $\mathrm{CdSe}-\mathrm{Pt} / \mathrm{TiO}_{2}$ under visible light $[26,56]$, indicating the superiority of $\mathrm{TiO}_{2}$-based photocatalysts.

Single crystalline $\mathrm{Zn}_{2} \mathrm{GeO}_{4}$ nanoribbons with a thickness as small as $7 \mathrm{~nm}$, a width of $20-50 \mathrm{~nm}$, and a length of hundreds of micrometers were applied in the photoreduction of $\mathrm{CO}_{2}$ in the presence of water [57]. The band-gap value of the nanoribbons was estimated to $4.5 \mathrm{eV}$, and their specific surface area was $28 \mathrm{~m}^{2} \mathrm{~g}^{-1}$. The methane formation rate $(0.41$ $\mu \mathrm{mol} \mathrm{h}{ }^{-1} \mathrm{~g}_{\text {cat }}{ }^{-1}$ ) for $13-16 \mathrm{~h}$ under light using the $\mathrm{Zn}_{2} \mathrm{GeO}_{4}$ nanoribbons increased to $1.9 \mu \mathrm{mol}$ $\mathrm{h}^{-1} \mathrm{~g}_{\mathrm{cat}}{ }^{-1}$ with the addition of $1 \mathrm{wt}^{2} \% \mathrm{RuO}_{2}$, and further to $6.5 \mu \mathrm{mol} \mathrm{h}{ }^{-1} \mathrm{gcat}^{-1}$ with the further addition of $1 \mathrm{wt} \% \mathrm{Pt}$ (Table 1C). The crystalline nanoribbons were suggested to suppress charge recombination and facilitate charge transport from the bulk to the surface-active sites. Zinc germanium oxynitride was prepared from $\mathrm{Zn}_{2} \mathrm{GeO}_{4}$ with ammonia at $1073 \mathrm{~K}$ [58]. The band gap increased to $2.70 \mathrm{eV}$, and the rate of $\mathrm{CO}_{2}$ photoreduction to methane increased. The positive shift of the top of the valence band was considered to enhance water photooxidation and effectively supply the produced protons to the $\mathrm{CO}_{2}$.

Layered-perovskite photocatalysts $\mathrm{A}^{\mathrm{II}} \mathrm{La}_{4} \mathrm{Ti}_{4} \mathrm{O}_{15}(\mathrm{~A}=\mathrm{Ca}, \mathrm{Sr}$, and $\mathrm{Ba})$ that have been reported for complete water splitting [59] were recently applied to the $\mathrm{CO}_{2}$ photoreduction 
[60]. In a series of photocatalytic tests in $\mathrm{CO}_{2}$-saturated water under a 400-W Hg lamp, $\mathrm{CO}$ was formed in a competitive reaction to produce $\mathrm{H}_{2}$ and a minor amount of formic acid. The reactivity order to form $\mathrm{CO}$ was

$$
\begin{aligned}
& \operatorname{Ag}(2 \mathrm{wt} \%)-\mathrm{BaLa}_{4} \mathrm{Ti}_{4} \mathrm{O}_{15}-\mathrm{LPR}(73)>\operatorname{Ag}(1 \mathrm{wt} \%)-\mathrm{CaLa}_{4} \mathrm{Ti}_{4} \mathrm{O}_{15}-\mathrm{LPR}(31) \\
& >\operatorname{Ag}(1 \mathrm{wt} \%)-\mathrm{SrLa}_{4} \mathrm{Ti}_{4} \mathrm{O}_{15}-\mathrm{LPR}(24)>\operatorname{Ag}(1 \mathrm{wt} \%)-\mathrm{BaLa}_{4} \mathrm{Ti}_{4} \mathrm{O}_{15}-\mathrm{PD}(14) \\
& >\mathrm{Ag}(1 \mathrm{wt} \%)-\mathrm{CaLa}_{4} \mathrm{Ti}_{4} \mathrm{O}_{15}-\mathrm{PD}(7.7)>\mathrm{Ag}(1 \mathrm{wt} \%)-\mathrm{SrLa}_{4} \mathrm{Ti}_{4} \mathrm{O}_{15}-\mathrm{PD}(6.0),
\end{aligned}
$$

where LPR and PD indicate Ag doping to photocatalysts by liquid-phase reduction and photodeposition, respectively, and the values in the parentheses are the $\mathrm{CO}$ formation rates in the unit of $\mu \mathrm{mol} \mathrm{h}^{-1} \mathrm{~g}_{\mathrm{cat}}^{-1}$ (Table 1C). The formation rates of the by-product formic acid were 4.3-1.0 $\mu \mathrm{mol} \mathrm{h}^{-1} \mathrm{~g}_{\mathrm{cat}}{ }^{-1}$. Silver nanoparticles of $\sim 10 \mathrm{~nm}$ on the edge sites of the layered $\mathrm{BaLa}_{4} \mathrm{Ti}_{4} \mathrm{O}_{15}$ were suggested to be favorable for the reduction of $\mathrm{CO}_{2}$ to $\mathrm{CO}$.

$$
\begin{gathered}
\left.2 \mathrm{H}_{2} \mathrm{O}+4 h^{+} \text {(basal plane of } \mathrm{BaLa}_{4} \mathrm{Ti}_{4} \mathrm{O}_{15}\right) \rightarrow 4 \mathrm{H}^{+}+\mathrm{O}_{2}, E^{\circ}(298 \mathrm{~K})=+1.229 \mathrm{~V} \\
\mathrm{CO}_{2}+2 \mathrm{H}^{+}+2 e^{-}(\text {Ag nanoparticles on the edge }) \rightarrow \mathrm{CO}+\mathrm{H}_{2} \mathrm{O}, E^{\circ}(298 \mathrm{~K})=-0.11 \mathrm{~V}
\end{gathered}
$$

It was also discussed that the spacial separation of the oxidation and reduction sites suppressed the reverse reaction of $\mathrm{CO}$ to $\mathrm{CO}_{2}$.

The chemistry of metal-organic frameworks (MOFs) has recently attracted attention owing to the freedom of element choice and the size of the micro/mesopore for realizing designed chemical functions, such as sorption and catalysis. The immobilization of homogeneous photocatalysts for the $\mathrm{CO}_{2}$ photoreduction to an MOF [61] can be compared to the semiconductor-type photocatalysts in this review. Among the various homogeneous photocatalysts for the $\mathrm{CO}_{2}$ photoreduction, including cobalt, nickel, iron, and rhenium complexes [6], $\operatorname{Re}^{\mathrm{I}}(\mathrm{CO})_{3}(\mathrm{dcbpy}) \mathrm{Cl}(4.2 \mathrm{wt} \%$; dcbpy = 2,2'-bipyridine-5,5'-dicarboxylic acid) was incorporated to a $\mathrm{Zr}_{6} \mathrm{O}_{4}(\mathrm{OH})_{4}(\mathrm{bpdc})$ (bpdc = para-biphenyl-dicarboxylic acid) framework. When the catalyst was placed in $\mathrm{CO}_{2}$-saturated acetonitrile including triethylamine as a sacrificial electron donor under UV-visible light from a 450-W xenon lamp (>300 nm), the turnover number to CO was $10.9 \mathrm{in} 20 \mathrm{~h}$, corresponding to $42 \mu \mathrm{mol} \mathrm{g}_{\mathrm{cat}}{ }^{-1} \mathrm{~h}^{-1}$. 
The amount of catalyst includes both the Re complex and the MOF. After the 20-h reaction, $43.6 \%$ of the Re leached into the supernatant, indicating the detachment of the Re carbonyl species from the MOF.

When $\operatorname{Re}^{\mathrm{I}}(\mathrm{CO})_{3}(\mathrm{dcbpy}) \mathrm{Cl}$ was used as a homogeneous photocatalyst under similar conditions, the turnover number to CO was 3.5 (corresponding to $760 \mu \mathrm{mol} \mathrm{g}_{\mathrm{cat}}{ }^{-1} \mathrm{~h}^{-1}$ ) in $6 \mathrm{~h}$, but the catalyst deactivated after $6 \mathrm{~h}$, even when triethylamine was added to the reaction system at $6 \mathrm{~h}$. Control reactions were also reported in the absence of $\mathrm{CO}_{2}$, in the dark, and in solvent labeled with isotopic $\mathrm{CD}_{3} \mathrm{CN}$, and the lack of formic acid/methanol formation was confirmed by proton nuclear magnetic resonance $\left({ }^{1} \mathrm{H}-\mathrm{NMR}\right)$ spectroscopy. These results strongly suggested the photocatalytic formation of $\mathrm{CO}$, but recyclability tests indicated that catalyst deactivation occurred after two 6-h reaction runs [61].

If the scope of this review is widened to include photocatalysts that require a sacrificial electron donor in order to reduce the $\mathrm{CO}_{2}$, colloidal $\mathrm{ZnS}[62,63]$ and $\mathrm{CdS}[64,65]$ nanoparticles should be considered. These catalysts formed formic acid and $\mathrm{CO}$ with high quantum yields when excited under UV-visible light $[62,63,65]$ or visible light only $(>400$ nm) [64].

In summary, $\mathrm{CdS}, \mathrm{SiC}, \mathrm{InNbO}_{4}, \mathrm{HNb}_{3} \mathrm{O}_{8}, \mathrm{BiWO}_{6}$, promoted $\mathrm{NaNbO}_{3}$, and promoted $\mathrm{Zn}_{2} \mathrm{GeO}_{4}$ produced methane or methanol with rates of $1-10 \mu \mathrm{mol} \mathrm{h}^{-1} \mathrm{~g}_{\text {cat }}{ }^{-1}$, and promoted $\mathrm{A}^{\mathrm{II}} \mathrm{La}_{4} \mathrm{Ti}_{4} \mathrm{O}_{15}$ produced $\mathrm{CO}$ with a rate greater than $10 \mu \mathrm{mol} \mathrm{h}{ }^{-1} \mathrm{~g}_{\text {cat }}{ }^{-1}$. The more negative conduction band energy for $\mathrm{CdS}, \mathrm{SiC}, \mathrm{Nb}$, and $\mathrm{Ta}$ seems to be one of the key factors for effective $\mathrm{CO}_{2}$ photoreduction $[14,59,66]$. A homogeneous Re complex supported on an MOF improved the life of the homogeneous photocatalyst.

\subsection{Carbon-based photocatalysts}

Small carbon nanoparticles of less than $10 \mathrm{~nm}$ can be covalently functionalized e.g., with PEG, to give them strong absorption and emission properties in the visible light region. 
Gold was photoreduced onto functionalized $\mathrm{C}$ nanoparticles, and the photocatalytic conversion of $\mathrm{CO}_{2}$ to formic acid in an aqueous solution was reported with a quantum yield of $0.3 \%$ based on ${ }^{1} \mathrm{H}-\mathrm{NMR}$ analysis [67], but detailed quantitative kinetic data were not shown in the paper. Semiconductor-like charge separation was suggested, and the advantage of the Au-functionalized $\mathrm{C}$ was claimed due to the aqueous solubility. Separately, efficient CO formation was reported using graphitic carbon nitride under visible light ( $>420 \mathrm{~nm})$; however, it is essential to verify whether the $\mathrm{CO}$ was derived from $\mathrm{CO}_{2}$, and not from the surface functional groups or the carbon nitride itself, before any further discussion is warranted [68].

A solvent-exfoliated graphene (SEG) dispersion, obtained via the ultrasonic treatment and centrifugation of natural graphite in $N, N$-dimethylformamide, was mixed with $\mathrm{TiO}_{2}(\mathrm{P} 25)$ and ethyl cellulose to form films that were calcined at $673 \mathrm{~K}$ [69]. The rate of photoreduction of $\mathrm{CO}_{2}$ to methane using the SEG $(0.27 \mathrm{wt} \%)-\mathrm{TiO}_{2}\left(8.3 \mu \mathrm{mol} \mathrm{h}{ }^{-1} \mathrm{~m}^{-2}\right)$ was 4.5 times greater than that using $\mathrm{TiO}_{2}(\mathrm{P} 25)$ under UV light. The less-defective SEG was a better photocatalytic promoter than reduced graphene oxide, demonstrating an electric diffusion effect, rather than the presence of reactive defect sites.

A disorder-engineered black $\mathrm{TiO}_{2}$ photocatalyst prepared by hydrogenation at $473 \mathrm{~K}$ was reported to be effective for the water reduction reaction with the use of a sacrificial electron donor. A mid-gap electronic state resulting from the introduction of the structural disorder was assumed to change the powder color and shorten the band gap. The color was stable for more than a year [70]. Unfortunately, the black color was later reported to be due to the presence of $\sim 0.6 \mu \mathrm{mol}$ of chromium contained per unit gram of the $\mathrm{TiO}_{2}$ nanotubes, which originated from the passivating $\mathrm{Cr}$ oxide layer of the stainless steel autoclave [71]. The visible light response using metal-cation-doped $\mathrm{TiO}_{2}$ photocatalysts has already been established as being due to the impurity energy level below the conduction band [36,72-74]. Although dark blue $\mathrm{TiO}_{2}$ with structural disorder that was free from $\mathrm{Cr}$ was instantly oxidized back to white $\mathrm{TiO}_{2}$ at room temperature in air, the application of $\mathrm{TiO}_{2}$ with structural disorder 
to the $\mathrm{CO}_{2}$ photoreduction is expected.

\section{Photon energy conversion of $\mathrm{CO}_{2}$ to fuels using hydrogen}

\subsection{Photocatalytic conversion of $\mathrm{CO}_{2}$ to methane or $\mathrm{CO}$ using hydrogen}

The reduction of $\mathrm{CO}_{2}$ with hydrogen is thermodynamically favorable compared to the reduction with water $\left(\Delta G_{\mathrm{r}}{ }^{\circ}=+689 \mathrm{~kJ} \mathrm{~mol}^{-1}\right.$; Section 3.5) as follows.

$$
\begin{aligned}
& \mathrm{CO}_{2}(g)+3 \mathrm{H}_{2}(g) \rightarrow \mathrm{CH}_{3} \mathrm{OH}(g)+\mathrm{H}_{2} \mathrm{O}(g), \Delta G_{\mathrm{r}}^{\circ}=+2.9 \mathrm{~kJ} \mathrm{~mol}^{-1} \\
& \mathrm{CO}_{2}(g)+4 \mathrm{H}_{2}(g) \rightarrow \mathrm{CH}_{4}(g)+2 \mathrm{H}_{2} \mathrm{O}(g), \Delta G_{\mathrm{r}}^{\circ}=-113.6 \mathrm{~kJ} \mathrm{~mol}^{-1}
\end{aligned}
$$

In this case, we assume that hydrogen is supplied via sustainable ways, e.g., photocatalytic water reduction utilizing sunlight $[59,75,76]$.

The reduction of $\mathrm{CO}_{2}$ to methane with $\mathrm{H}_{2}$ gas was first reported using $\mathrm{Ru} / \mathrm{RuO}_{x} / \mathrm{TiO}_{2}$ [77]. The initial formation rate of methane was $49 \mu \mathrm{mol} \mathrm{h}^{-1} \mathrm{~g}_{\mathrm{cat}}{ }^{-1}$ at $319 \mathrm{~K}$ using light from a solar simulator with a total intensity of $80 \mathrm{~mW} \mathrm{~cm}^{-2}$ (Table 2). The $\mathrm{CO}_{2}$ conversion was believed to be due to thermal and UV light effects. However, a later report concluded that it was solely a thermal effect [78]. Comparable or slower methane formation to that reported in reference 77 was reproduced at 295 and $373 \mathrm{~K}$ in the dark. The enhancement of methane formation by light was completely suppressed by placing a $25-\mathrm{mm}$ water filter on the $150-\mathrm{W}$ xenon lamp. Even when the irradiation power was varied between 2 and $350 \mathrm{~mW} \mathrm{~cm}^{-2}$, no change in the kinetic results was observed as long as the water filter was used.

The photoreduction of $\mathrm{CO}_{2}$ using hydrogen as a reductant has also been reported to produce carbon monoxide using $\mathrm{Rh} / \mathrm{TiO}_{2}\left(5.1 \mu \mathrm{mol} \mathrm{h}{ }^{-1} \mathrm{~g}_{\text {cat }}{ }^{-1}\right)$ [79], $\mathrm{ZrO}_{2}\left(0.56 \mu \mathrm{mol} \mathrm{h}{ }^{-1}\right.$ $\left.\mathrm{g}_{\text {cat }}{ }^{-1}\right)$ [80], and $\mathrm{MgO}\left(1.6 \mu \mathrm{mol} \mathrm{h}{ }^{-1} \mathrm{~g}_{\text {cat }}{ }^{-1}\right)$ [81] under $\mathrm{CO}_{2}+\mathrm{H}_{2}$ (total $25 \mathrm{kPa}$ ) illuminated with a $\mathrm{Hg}$ lamp and $\beta-\mathrm{Ga}_{2} \mathrm{O}_{3}\left(0.76 \mu \mathrm{mol} \mathrm{h}{ }^{-1} \mathrm{~g}_{\text {cat }}{ }^{-1}\right)$ under $\mathrm{CO}_{2}+\mathrm{H}_{2}$ (total $3.2 \mathrm{kPa}$ ) illuminated with a $\mathrm{Hg}-\mathrm{Xe}$ lamp [82] (Table 2). When $\mathrm{TiO}_{2}$ and $\mathrm{ZrO}_{2}$ in $\mathrm{CO}_{2}+\mathrm{H}_{2}+\mathrm{H}_{2} \mathrm{O}$ and $\mathrm{CO}_{2}+\mathrm{H}_{2}$ were illuminated with UV light of 365 and $254 \mathrm{~nm}$ from a near-UV fluorescent black lamp, 
methane and CO were produced at rates of $4.1 \mu \mathrm{mol} \mathrm{h}{ }^{-1} \mathrm{~g}_{\mathrm{cat}}{ }^{-1}$ and $0.62 \mu \mathrm{mol} \mathrm{h}^{-1} \mathrm{~g}_{\mathrm{cat}}{ }^{-1}$, respectively [83].

In summary, rhodium was an effective additive, but only simple metal ( $\mathrm{Ti}, \mathrm{Zr}, \mathrm{Mg}$, and Ga) oxide semiconductors photoreduced $\mathrm{CO}_{2}$ with molecular $\mathrm{H}_{2}$ at a rate of $\sim 1 \mu \mathrm{mol} \mathrm{h}{ }^{-1}$ $\mathrm{g}_{\text {cat }}{ }^{-1}$.

\subsection{Photocatalytic conversion of $\mathrm{CO}_{2}$ to methanol using hydrogen}

Layered-double hydroxide (LDH) compounds are a family of clays, but their layers are positively charged in contrast to more general clays, in which the layers are negatively charged, e.g., the smectite and vermiculite families [3,84-86]. LDHs are materials based on the layered structure of brucite $\left(\mathrm{Mg}(\mathrm{OH})_{2}\right)$, which has a hexagonal crystal structure in which the $\mathrm{MgO}_{6}$ octahedra are linked at the edge to form sheets. One of the naturally occurring LDH compounds is hydrotalcite. The charge of cationic sheets formulated as $\left[\mathrm{M}^{\mathrm{II}}{ }_{1-x} \mathrm{M}^{\mathrm{III}}{ }_{x}(\mathrm{OH})_{2}\right]^{x+}$ is compensated with an intercalated anion group, e.g., $\mathrm{CO}_{3}{ }^{2-}, \mathrm{SO}_{4}{ }^{2-}$, $\mathrm{NO}_{3}{ }^{-}, \mathrm{Cl}^{-}$, or $\mathrm{OH}^{-}$. The $\mathrm{M}^{\mathrm{II}}$ site can be $\mathrm{Mg}, \mathrm{Mn}, \mathrm{Fe}, \mathrm{Co}, \mathrm{Ni}, \mathrm{Cu}$, or $\mathrm{Zn}$, and the $\mathrm{M}^{\mathrm{III}}$ site can be $\mathrm{Al}, \mathrm{Cr}, \mathrm{Mn}, \mathrm{Fe}$, or Ga. The value of the variable $x$ is normally within the range $0.17-0.33$. The molar amount of structural water intercalated between the cationic layers is about half of the total molar amount of metal cations.

LDH compounds have already been applied to photocatalytic water oxidation $[87,88]$. $\mathrm{Zn}_{4} \mathrm{Ti}^{\mathrm{IV}}{ }_{x}, \mathrm{Zn}_{4} \mathrm{Ce}^{\mathrm{III}}{ }_{x}$, and $\mathrm{Zn}_{4} \mathrm{Cr}^{\mathrm{III}}{ }_{x}(0.25<x<2) \mathrm{LDH}$ compounds exhibited good quantum yields for photocatalytic water oxidation in the presence of silver nitrate as a sacrificial oxidizing reagent under visible light $(>400 \mathrm{~nm})$ [87]. The LDH compound $\left[\mathrm{Zn}_{0.69} \mathrm{Cr}^{\mathrm{III}}{ }_{0.31}(\mathrm{OH})_{2}\right]^{0.31+} 0.31 \mathrm{NO}_{3}{ }^{-} \cdot 0.6 \mathrm{H}_{2} \mathrm{O}$ and the nanohybrid material $\mathrm{Zn}-\mathrm{Cr} \mathrm{LDH}$ and layered titanate were also effective for photocatalytic water oxidation in the presence of 0.01 $\mathrm{M} \mathrm{AgNO}_{3}$ as a sacrificial oxidizing reagent under visible light $(>420 \mathrm{~nm})$ [88].

Ordered LDHs consisting of zinc and/or copper hydroxides combined with aluminum 
have been reported to be good photocatalysts for the conversion of gaseous $\mathrm{CO}_{2}$ to methanol or CO under UV-visible light using hydrogen [3]. The LDH compound $\left[\mathrm{Zn}_{3} \mathrm{Al}^{\mathrm{III}}(\mathrm{OH})_{8}\right]_{2}^{+}\left(\mathrm{CO}_{3}\right)^{2-} \cdot m \mathrm{H}_{2} \mathrm{O}$ (band gap: $5.7 \mathrm{eV}$ ) was the most active for the $\mathrm{CO}_{2}$ photoreduction, and the major product was $\mathrm{CO}$, which formed at a rate of $0.62 \mu \mathrm{mol} \mathrm{h}^{-1} \mathrm{~g}_{\mathrm{cat}}{ }^{-1}$, along with minor amounts of methanol (Table 2). The methanol selectivity (5.9 mol\%) modestly increased to $26 \%$, but the total photoactivity decreased, when $\mathrm{Cu}$ sites were introduced in the $\mathrm{LDH}$, i.e., $\left[\mathrm{Zn}_{1.5} \mathrm{Cu}_{1.5} \mathrm{Al}(\mathrm{OH})_{8}\right]_{2}^{+}\left(\mathrm{CO}_{3}\right)^{2-} \cdot m \mathrm{H}_{2} \mathrm{O}$ (band gap: $4.1 \mathrm{eV}$ ). The $\mathrm{CO}_{2}$ conversion was $0.16-0.11 \%$ using $\left[\mathrm{Zn}_{3-x} \mathrm{Cu}_{x} \mathrm{Al}(\mathrm{OH})_{8}\right]_{2}^{+}\left(\mathrm{CO}_{3}\right)^{2-} \cdot m \mathrm{H}_{2} \mathrm{O}(0 \leq x \leq 1.5)$ photocatalysts.

Ordered LDHs consisting of zinc and/or copper hydroxides combined with gallium were synthesized, and the methanol formation rate and selectivity using $\left[\mathrm{Zn}_{1.5} \mathrm{Cu}_{1.5} \mathrm{Ga}^{\mathrm{III}}(\mathrm{OH})_{8}\right]_{2}^{+}\left(\mathrm{CO}_{3}\right)^{2-} \cdot m \mathrm{H}_{2} \mathrm{O} \mathrm{LDH}$ (band gap: $3.5 \mathrm{eV}$ ) were $0.17 \mu \mathrm{mol} \mathrm{h}^{-1} \mathrm{~g}_{\text {cat }}{ }^{-1}$ and 68 mol\%, respectively. The $\mathrm{CO}_{2}$ conversion was $0.03-0.02 \%$ using $\left[\mathrm{Zn}_{3-x} \mathrm{Cu}_{x} \mathrm{Ga}(\mathrm{OH})_{8}\right]_{2}^{+}\left(\mathrm{CO}_{3}\right)^{2-} \cdot m \mathrm{H}_{2} \mathrm{O}(0 \leq x \leq 1.5)$ photocatalysts. The specific interaction of the $\mathrm{Cu}$ sites with $\mathrm{CO}_{2}$ was spectroscopically suggested (based on XANES analysis) to enable coupling with protons and photogenerated electrons to form the methanol. The participation of $\mathrm{Cu}$ sites in the redox process in the $\mathrm{CO}_{2}$ photoreduction was also suggested [5].

The rate of photoconversion of $\mathrm{CO}_{2}$ to methanol was improved to $0.49 \mu \mathrm{mol} \mathrm{h}^{-1} \mathrm{~g}_{\mathrm{cat}}{ }^{-1}$ by replacing the interlayer carbonate anions of $\left[\mathrm{Zn}_{1.5} \mathrm{Cu}_{1.5} \mathrm{Ga}(\mathrm{OH})_{8}\right]_{2}^{+}\left(\mathrm{CO}_{3}\right)^{2-} \cdot m \mathrm{H}_{2} \mathrm{O}$ with $\left[\mathrm{Cu}(\mathrm{OH})_{4}\right]^{2-}$, and the methanol selectivity increased to $88 \mathrm{~mol} \%$ [4]. The band-gap value of the improved LDH catalyst was $3.0 \mathrm{eV}$. A direct electronic transition from the $\mathrm{O} 2 \mathrm{p}$ to the metal $3 \mathrm{~d}, 4 \mathrm{~s}$, or $4 \mathrm{p}$ was suggested for the photocatalysis excited largely by UV.

No chemicals containing carbon atoms were used throughout the synthesis of the LDH compounds $\left[\mathrm{Zn}_{3-x} \mathrm{Cu}_{x} \mathrm{~A}(\mathrm{OH})_{8}\right]_{2}^{+} \mathrm{X}^{2-} \cdot m \mathrm{H}_{2} \mathrm{O}\left(\mathrm{A}=\mathrm{Al}, \mathrm{Ga} ; \mathrm{X}=\mathrm{CO}_{3}, \mathrm{Cu}(\mathrm{OH})_{4} ; 0 \leq x \leq 1.5\right)$ except for sodium carbonate, or during the pretreatment prior to the catalytic tests. After the synthesis of the $\mathrm{LDH}$, the powder was thoroughly washed using deionized water $(<1.0 \mu \mathrm{S}$ 
$\mathrm{cm}^{-1}$ ) before drying. The sodium carbonate was the source of the interlayer anions, and the products produced in the reaction were essentially identical with the species derived from the photoconversion of gas-phase $\mathrm{CO}_{2}$. Furthermore, no products were detected when the $\left[\mathrm{Zn}_{1.5} \mathrm{Cu}_{1.5} \mathrm{Ga}(\mathrm{OH})_{8}\right]_{2}^{+}\left(\mathrm{CO}_{3}\right)^{2-} \cdot m \mathrm{H}_{2} \mathrm{O}$ compound was suspended in deionized water under UV-visible light for $5 \mathrm{~h}$ [3]. Thus, the possibility [38,39] that carbon impurities that accumulated during the $\mathrm{LDH}$ catalyst preparation and/or activation before the kinetic tests were conducted was converted rather than $\mathrm{CO}_{2}$ is not plausible in references 3 and 4.

However, the possibility of a thermal reaction should also be seriously considered [77,78]. The in-process spectra for $\left[\mathrm{Zn}_{3} \mathrm{Ga}(\mathrm{OH})_{8}\right]_{2}^{+}\left(\mathrm{CO}_{3}\right)^{2-} \cdot m \mathrm{H}_{2} \mathrm{O}$ and $\left[\mathrm{Zn}_{1.5} \mathrm{Cu}_{1.5} \mathrm{Ga}(\mathrm{OH})_{8}\right]_{2}^{+}\left(\mathrm{CO}_{3}\right)^{2-} \cdot m \mathrm{H}_{2} \mathrm{O}$ during the photoreaction in $\mathrm{CO}_{2}+\mathrm{H}_{2}$ were reported (Figure 6). The formation of both $\mathrm{CO}$ and methanol reached a maximum at a wavelength of $400 \mathrm{~nm}$ both for $\left[\mathrm{Zn}_{3} \mathrm{Ga}(\mathrm{OH})_{8}\right]_{2}^{+}\left(\mathrm{CO}_{3}\right)^{2-} \cdot m \mathrm{H}_{2} \mathrm{O}$ and $\left[\mathrm{Zn}_{1.5} \mathrm{Cu}_{1.5} \mathrm{Ga}(\mathrm{OH})_{8}\right]^{+}{ }_{2}\left(\mathrm{CO}_{3}\right)^{2-} \cdot m \mathrm{H}_{2} \mathrm{O}$ (Figure 6, inset).

This trend is in clear contrast to methane formation using $\mathrm{Ru} / \mathrm{RuO}_{x} / \mathrm{TiO}_{2}$. At fixed temperature $(319 \mathrm{~K})$ in $\mathrm{CO}_{2}+\mathrm{H}_{2}$, the methane formation rate increased by 2.8 times when the reaction mixture was irradiated with light from a solar simulator [77], but a second study found that the light effect was due to an increase in the temperature from 298 to $314 \mathrm{~K}$ and suggested the temperature control in reference 77 was not exact. When a water filter was inserted between the catalyst and a 150-W xenon lamp, no effect of the light was observed [78]. In contrast, when a water filter was inserted for the $\left[\mathrm{Zn}_{1.5} \mathrm{Cu}_{1.5} \mathrm{Al}(\mathrm{OH})_{8}\right]_{2}^{+}\left(\mathrm{CO}_{3}\right)^{2-} \cdot m \mathrm{H}_{2} \mathrm{O}$ catalyst (Figure $7 \mathrm{~B}$ ), the methanol and $\mathrm{CO}$ formation rates increased (Table 2) owing to an increase in the UV + visible light intensity from $42 \mathrm{~mW}$ $\mathrm{cm}^{-2}$ (Figure $7 \mathrm{~A}$ ) to $106 \mathrm{~mW} \mathrm{~cm}{ }^{-2}$ (Figure 7B). The maximum temperature during these photocatalytic reactions was $313 \mathrm{~K}$, but a control reaction using $\left[\mathrm{Zn}_{1.5} \mathrm{Cu}_{1.5} \mathrm{Al}(\mathrm{OH})_{8}\right]_{2}^{+}\left(\mathrm{CO}_{3}\right)^{2-} \cdot m \mathrm{H}_{2} \mathrm{O}$ in the dark at 296-313 $\mathrm{K}[3,89]$ under $\mathrm{CO}_{2}+\mathrm{H}_{2}$ exhibited no conversion above the detection limit of the GC. Thus, the catalysis using LDH 
compounds under $\mathrm{CO}_{2}+\mathrm{H}_{2}$ proceeded photocatalytically.

In summary, using $\mathrm{LDH}$ photocatalysts consisting of $\mathrm{Zn}, \mathrm{Cu}, \mathrm{Al}$, and $\mathrm{Ga}$, both $\mathrm{CO}$ and methanol were formed at rates of $0.1-1 \mu \mathrm{mol} \mathrm{h}^{-1} \mathrm{~g}_{\text {cat }}{ }^{-1}$.

\section{Photon energy conversion of $\mathrm{CO}_{2}$ to fuels using a new reaction system}

\subsection{Recycling of sacrificial electron donors}

The regeneration of a sacrificial electron donor in the photoreduction of $\mathrm{CO}_{2}$ was reported $[8,90]$ to make the overall catalytic reaction system cyclic. The tricyclic tertiary amine 10-endo-anti-11-aza-10-methoxy-11-methyltricyclo $\left[4.3 .1 .1^{2,5}\right]$ undecane was selected as the sacrificial electron donor (Figure 8). An electron, a proton, and a hydrogen atom were donated by the amine, and the $\mathrm{CO}_{2}$ was converted to formic acid using a $p$-terphenyl photocatalyst under irradiation from a $\mathrm{Hg}$ lamp at $254 \mathrm{~nm}$. The amine was transformed to the stable alkene 10-endo-anti-11-aza-10-methoxy-11-methyltricyclo [4.3.1.1 $\left.{ }^{2,5}\right]$ undec-7-ene. The alkene was successfully hydrogenated back to the original alkane using a $\mathrm{Pd} / \mathrm{C}$ catalyst. In reference 90, the hydrogen was assumed to be generated from the photosplitting of water, similar to the photocatalytic $\mathrm{CO}_{2}$ reduction using $\mathrm{H}_{2}$ in references 3 and 4 .

\subsection{Photoconversion of $\mathrm{CO}_{2}$ to fuels utilizing anode oxidation and cathode reduction} compartments

Various photocatalysts for the photooxidation of water have been reported $[59,75,91,92]$. The idea of an artificial dark reaction following water photooxidation was also proposed $[7,9,93]$.

In 2006, a solar fuel cell was proposed on the basis of the concept of a polymer electrolyte fuel cell (PEFC) and a phosphoric acid fuel cell consisting of an electrolyte for the transfer of protons from the anode side to the cathode side. A solar photovoltaic assembly 
was proposed to separate the holes and electrons, an anode catalyst to oxidize water using the holes, and a cathode catalyst to reduce the protons to hydrogen using the electrons (Figure 9). In photosynthesis, protons are reduced by Photosystem I to hydrogen equivalents. In other words, electrons are stored through the conversion of NADP to NADPH. Thus, if the photon conversion device is based on a single-bandgap absorber consisting of a semiconductor, the theoretical thermodynamic conversion efficiency is $32 \%$ in unconcentrated sunlight [9].

A dye-sensitized solar cell utilizing a polymer membrane and a manganese catalyst was proposed in 2009 [93]. Inspired by Photosystem II, in which a cube-shaped Ca-Mn oxide catalyst oxidizes water to $\mathrm{O}_{2}$, protons, and electrons, the synthetic model Mn oxide cluster complex $\mathrm{Mn}_{4} \mathrm{O}_{4}$ was incorporated into a proton-conducting membrane, e.g., Nafion. The complex and an $\mathrm{H}^{+}$-conducting membrane were integrated into a solar cell (Figure 10). An organic ruthenium dye captured sunlight, and the excited electrons were injected into the neighboring $\mathrm{TiO}_{2}$ nanoparticles. The manganese catalyst also captured sunlight and oxidized water. The grabbed electrons from the water were passed from the Mn catalyst to the dye molecules. The electrons were transmitted to the cathode via an external circuit, while the protons transmitted through the $\mathrm{H}^{+}$-conducting membrane were reduced to $\mathrm{H}_{2}$ on the cathode catalyst with the electrons. A solar cell (or solar fuel cell using water as the fuel) integrating an $\mathrm{H}^{+}$-conducting membrane and an iridium oxide catalyst was also reported.

The concept of the combined photocatalytic reduction of $\mathrm{CO}_{2}$ was also proposed in 2010 [7]. In this system, a water oxidation catalyst releases protons and electrons, followed by competitive reduction reactions of the protons to form $\mathrm{H}_{2}$ and react with $\mathrm{CO}_{2}$ to form fuel(s) (Figure 11). If good ligands are chosen for the homogeneous water oxidation catalyst complexes, $\mathrm{O}_{2}$ molecule formation is synchronized with the removal of the $\mathrm{H}^{+}$and the electrons. However, the drawback of rapid deactivation often exists because of the decomposition of the finely tuned ligands, e.g., heterocyclic organic compounds. Heterogeneous catalysts for water oxidation may be more stable and self-reparable. 
The feasibility of using methanol oxidation as a source of $\mathrm{H}_{2}$ in a PEFC [94] was also investigated. The fuel cell catalysts consisted of a $\mathrm{TiO}_{2}$ photocatalyst for the oxidation of methanol to $\mathrm{CO}_{2}$ and a Pt catalyst to reduce the protons to $\mathrm{H}_{2}$. The two catalysts were separated by an $\mathrm{H}^{+}$-conducting polymer (Figure 12). The amount of $\mathrm{TiO}_{2}$ was optimized to $3.0 \mathrm{mg} \mathrm{cm}{ }^{-2}$ on carbon paper, and the $\mathrm{Pt}-\mathrm{C}$ at $0.2 \mathrm{mg} \mathrm{cm}^{-2}$ on $\mathrm{C}$ paper, depending on the catalytic rate of each. Under UV-visible light illumination $\left(100 \mathrm{~mW} \mathrm{~cm}^{-2}\right)$ using a $\mathrm{Cu}$ sulfate filter for the anode $\left(\mathrm{TiO}_{2}\right)$ in a $1 \mathrm{M}$ methanol solution, $0.1 \mathrm{M} \mathrm{H}_{2} \mathrm{SO}_{4}$ as the electrolyte, and $(\mathrm{Pt}-\mathrm{C})$ as the cathode in a $0.1 \mathrm{M} \mathrm{H}_{2} \mathrm{SO}_{4}$ solution, a short circuit current of $0.34 \mathrm{~mA} \mathrm{~cm}^{-2}$ was obtained. Under similar reaction conditions, hydrogen was produced at a rate of 3.5 $\mu \mathrm{mol} \mathrm{h}{ }^{-1} \mathrm{~cm}^{-2}\left(1.2 \mathrm{mmol} \mathrm{h}^{-1} \mathrm{~g}_{\mathrm{TiO}_{2}}^{-1}\right)$. The photocatalytic reaction at the anode was proposed to proceed as follows.

$$
\begin{gathered}
h v \\
\mathrm{TiO}_{2} \rightarrow h^{+}+e^{-} \\
\mathrm{CH}_{3} \mathrm{OH}+h^{+} \rightarrow \mathrm{CH}_{3} \mathrm{O}+\mathrm{H}^{+} \\
\cdot \mathrm{CH}_{3} \mathrm{O}+\mathrm{H}_{2} \mathrm{O} \rightarrow \mathrm{CO}_{2}+5 \mathrm{H}^{+}+5 e^{-} \\
2 \mathrm{H}^{+}+2 e^{-} \rightarrow \mathrm{H}_{2}
\end{gathered}
$$

In total, hydrogen was produced by the photocatalytic decomposition of methanol, and a stoichiometric electric current was obtained for the overall reaction: $\mathrm{CH}_{3} \mathrm{OH}+\mathrm{H}_{2} \mathrm{O} \rightarrow \mathrm{CO}_{2}$ $+3 \mathrm{H}_{2}$. This study described the reverse reaction of the photocatalytic conversion of $\mathrm{CO}_{2}$, but also utilized a Pt electrocatalyst to reduce protons to $\mathrm{H}_{2}$ using a PEFC.

It is well known that plants and cyanobacteria use the reducing power generated by light-driven water oxidation in Photosystem II to produce NADPH by reducing the protons in Photosystem I [95].

$$
\begin{gathered}
2 \mathrm{H}_{2} \mathrm{O} \rightarrow \mathrm{O}_{2}+4 \mathrm{H}^{+}+4 e^{-}\left(\text {Photosystem II), } E^{\circ}(\mathrm{pH} 7)=+0.815 \mathrm{~V}\right. \\
\mathrm{NADP}^{+}+\mathrm{H}^{+}+2 e^{-} \rightarrow \text { NADPH (Photosystem I), } E^{\circ}(\mathrm{pH} 7)=-0.320 \mathrm{~V}
\end{gathered}
$$

The weak reductant formed by light energy in Photosystem II reduces the weak oxidant formed by different light energy in Photosystem I. This linked mechanistic model is called 
the Z-scheme. In 1982, artificial $\mathrm{H}_{2}$ formation starting from water was reported using a photodiode consisting of a Mg-doped p-type iron oxide and a Si-doped n-type iron oxide [96]. Using the combination of $\mathrm{Pt}-\mathrm{WO}_{3}$ for water oxidation and $\mathrm{Pt}-\mathrm{SrTiO}$ for water reduction, the stoichiometric $\mathrm{H}_{2}$ and $\mathrm{O}_{2}$ photocatalytic formation from water was also reported by applying the Z-scheme [97]. Furthermore, the separation of a $\mathrm{TiO}_{2}$ catalyst for water oxidation and a Pt- $\mathrm{TiO}_{2}$ catalyst for proton reduction by Nafion was reported to separately form $\mathrm{O}_{2}$ and $\mathrm{H}_{2}$ gas [98].

The concept of the Z-scheme was also applied to the photoreduction of $\mathrm{CO}_{2}$ using semiconductor catalysts for the water oxidation and homogeneous metal complex catalysts for the $\mathrm{CO}_{2}$ reduction. These studies have been previously reviewed as an extension of homogeneous photocatalysts of the photoreduction of $\mathrm{CO}_{2}$ [99].

The direct transfer of protons and electrons released from water oxidation catalysts to photocatalysts for the reduction of $\mathrm{CO}_{2}$ must be advantageous for achieving efficient rates for the photoconversion of $\mathrm{CO}_{2}$ to fuels. $\mathrm{A} \mathrm{Pt}-\mathrm{C}$ catalyst and an $\mathrm{LDH}$ photocatalyst $\left[\mathrm{Zn}_{1.5} \mathrm{Cu}_{1.5} \mathrm{Ga}^{\mathrm{III}}(\mathrm{OH})_{8}\right]_{2}^{+}\left(\mathrm{CO}_{3}\right)^{2-} \cdot m \mathrm{H}_{2} \mathrm{O}$ (see Section 4.2) were directly attached to a 50- $\mu$ m-thick proton-conducting membrane. The $\mathrm{CO}_{2}$ and water, supplied separately to each catalyst in the PEFC cell (Figure 13B), were converted to methanol at a rate of $5.1 \mu \mathrm{mol} \mathrm{h}{ }^{-1}$ $\mathrm{g}_{\mathrm{cat}(\mathrm{LDH})}{ }^{-1}$. It has also been found that heating at $413 \mathrm{~K}$ makes the membranes used in references 4 and 100 more $\mathrm{H}^{+}$-conductive. The development of a total photocatalytic system consisting of $\mathrm{WO}_{3}$ and $\mathrm{Zn}-\mathrm{Cu}-\mathrm{Ga} \mathrm{LDH}$ photocatalysts for the direct transfer of protons and electrons is underway [100].

\section{Concluding remarks}

The dramatic growth of renewable solar energy is needed. The initial investigation of the renewable energy options utilizing the thermochemical and photocatalytic conversion of 
$\mathrm{CO}_{2}$ to fuels has been reviewed. Semiconductor photocatalysts are advantageous if they are cheap and sustainable. Starting from $\mathrm{CO}_{2}$ and water, $\mathrm{TiO}_{2}$ photocatalytically produced methane at a rate of $\sim 0.1 \mu \mathrm{mol} \mathrm{h} \mathrm{g}_{\mathrm{cat}}^{-1}$. When $\mathrm{TiO}_{2}$ was atomically dispersed in Y-zeolite, MCM-48, or SBA-15, or doped $\mathrm{TiO}_{2}$ was used, the rate of methane or CO formation increased to 1-10 $\mu \mathrm{mol} \mathrm{h} \mathrm{h}^{-1} \mathrm{~g}_{\mathrm{cat}}^{-1}$. $\mathrm{CdS}, \mathrm{SiC}, \mathrm{InNbO}_{4}, \mathrm{HNb}_{3} \mathrm{O}_{8}, \mathrm{Bi}_{2} \mathrm{WO}_{6}, \mathrm{Pt}-\mathrm{NaNbO}_{3}$, and $\mathrm{RuO}_{2}-\mathrm{Pt}-\mathrm{Zn}_{2} \mathrm{GeO}_{4}$ produced methane or methanol at rates greater than $1 \mu \mathrm{mol} \mathrm{h}{ }^{-1} \mathrm{~g}_{\text {cat }}{ }^{-1}$, and $\mathrm{Ag}-\mathrm{BaLa}_{4} \mathrm{Ti}_{4} \mathrm{O}_{15}$ produced $\mathrm{CO}$ at a rate of $73 \mu \mathrm{mol} \mathrm{h}^{-1} \mathrm{gcat}^{-1}$.

The photocatalytic reduction of $\mathrm{CO}_{2}$ with molecular hydrogen was also surveyed. $\mathrm{CO}$ was formed at a rate of $\sim 1 \mu \mathrm{mol} \mathrm{h}^{-1} \mathrm{~g}_{\text {cat }}{ }^{-1}$ using $\mathrm{TiO}_{2}, \mathrm{ZrO}_{2}, \mathrm{MgO}$, and $\mathrm{Ga}_{2} \mathrm{O}_{3}$, while $\mathrm{CO}$ and methanol were formed at rates of $0.62 \mu \mathrm{mol} \mathrm{h}^{-1} \mathrm{~g}_{\mathrm{cat}}^{-1}$ and $0.49 \mu \mathrm{mol} \mathrm{h}^{-1} \mathrm{~g}_{\mathrm{cat}}{ }^{-1}$, respectively, using LDHs consisting of $\mathrm{Zn}, \mathrm{Cu}, \mathrm{Al}$, and $\mathrm{Ga}$.

Spectroscopic monitoring using ESR, EXAFS, XANES, photoluminescence, diffuse reflectance UV-visible, FTIR, and NMR techniques, and isotope monitoring using GC-MS and electron microscopy are essential for the verification of photocatalytic events and the source of $\mathrm{C}$ used to produce the fuels. The reaction mechanism of photocatalysis is still not well understood; e.g., the preferable formation of methane from $\mathrm{CO}_{2}+\mathrm{H}_{2} \mathrm{O}$ using $\mathrm{TiO}_{2}$ has not been explained. It should be more complex than the consecutive reduction from $\mathrm{CO}_{2}$ to formic acid (or $\mathrm{CO}$ ), the formyl group, formaldehyde, methoxy, methanol, and then methane [3] based on recent reports using ESR, which suggest formyl dimerization to glyoxal $(\mathrm{OHC}-\mathrm{CHO})$ as an intermediate of an efficient electron acceptor [101]. Theoretical understanding based on the comparison between band energy and the red-ox potential is in progress, but not enough to explain the product selectivity using $\mathrm{TiO}_{2}$ [102].

Further efficiency improvements for the $\mathrm{CO}_{2}$ conversion are highly expected by the combination of different photocatalysts (Section 4) and the use of new reaction systems (Section 5). In particular, the combination of water photosplitting to form hydrogen (or protons and electrons) and $\mathrm{CO}_{2}$ photoreduction with the formed hydrogen (or the formed 
protons and electrons) can potentially boost the efficiency of $\mathrm{CO}_{2}$ conversion.

\section{Acknowledgements}

The author thanks the Monbusho (MEXT) Research Fellowship for making it possible to do research as a Visiting Scientist in the Groups of Professor Solomon and Professor Hodgson during 1996-1997. The author is also grateful for financial support from the Grant-in-Aid for Scientific Research C (Proposal No. 2255 0117) from MEXT (2010-2012) and the Feasibility Study Stage of A-STEP (Proposal No. AS231Z01459C) from the Japan Science and Technology Agency for research related to this review.

\section{References}

[1] J. Tollefson, Nature 473 (2011) 134-135.

[2] A. Gore, An Inconvenient Truth, The Wylie Agency, London, UK, 2006, p.66.

[3] N. Ahmed, Y. Shibata, T. Taniguchi, Y. Izumi, J. Catal. 279 (2011) 123-135.

[4] N. Ahmed, M. Morikawa, Y. Izumi, Catal. Today, DOI: 10.1016/j.cattod.2011.08.010.

[5] A. Kubacka, M. F. García, G. Colón, Chem. Rev. 112 (2012) 1555-1614.

[6] A. J. Morris, G. J. Meyer, E. Fujita, Acc. Chem. Resear. 42 (2009) 1983-1994.

[7] J. K. Hurst, Science 328 (2010) 315-316.

[8] J. Michl, Nature Chem. 3 (2011) 268-269.

[9] N. S. Lewis, D. G. Nocera, Proc. Natl. Acad. Sci. U.S.A. 103 (2006) 15729-15735; 104 (2007) 20142.

[10] W. C. Chueh, C. Falter, M. Abbott, D. Scipio, P. Furler, S. M. Haile, A. Steinfeld, Science 330 (2010) 1797-1801.

[11] N. D. Petkovich, S. G. Rudisill, L. J. Venstrom, D. B. Boman, J. H. Davidson, A. Stein, J. Phys. Chem. C 115 (2011) 21022-21033.

[12] M. Grätzel, Nature 414 (2001) 338-344. 
[13] O. K. Varghese, M. Paulose, T. J. LaTempa, C. A. Grimes, Nano Lett. 9 (2009) 731-737.

[14] T. Inoue, A. Fujishima, S. Konishi, K. Honda, Nature 277 (1979) 637-638.

[15] S. S. Tan, L. Zou, E. Hu, Catal. Today 115 (2006) 269-273.

[16] M. Anpo, H. Yamashita, Y. Ichihashi, S. Ehara, J. Electroanal. Chem. 396 (1995) 21-26.

[17] A. Baiker, Chem. Rev. 99 (1999) 453-473.

[18] S. Kaneco, H. Kurimoto, Y. Shimizu, K. Ohta, T. Mizuno, Energy 24 (1999) 21-30.

[19] F. Solymosi, I. Tombácz, Catal. Lett. 27 (1994) 61-65.

[20] W. Wang, S. Wang, X. Ma, J. Gong, Chem. Soc. Rev. 40 (2011) 3703-3727.

[21] Y. Izumi, Y. Iwasawa, CHEMTECH 24 (1994) 20-27.

[22] Y. Izumi, T. Chihara, H. Yamazaki, Y. Iwasawa, J. Phys. Chem. 98 (1994) 594-602.

[23] Y. Izumi, Platinum Metals Rev. 41 (1997) 166-170.

[24] Y. Izumi, H. Kurakata, K. Aika, J. Catal. 175 (1998) 236-244.

[25] U. A. Joshi, A. Palasyuk, D. Arney, P. A. Maggard, Phys. Chem. Lett. 1 (2010) $2719-2726$.

[26] C. Wang, R. L. Thompson, J. Baltrus, C. Matranga, J. Phys. Chem. Lett. 1 (2010) 48-53.

[27] C. Wang, R. L. Thompson, P. Ohodnicki, J. Baltrus, C. Matranga, J. Mater. Chem. 21 (2011) 13452-13457.

[28] M. Anpo, H. Yamashita, Y. Ichihashi, Y. Fujii, M. Honda, J. Phys. Chem. B 101 (1997) $2632-2636$.

[29] M. Anpo, H. Yamashita, K. Ikeue, Y. Fujii, S. G. Zhang, Y. Ichihashi, D. R. Park, Y. Suzuki, K. Koyano, T. Tatsumi, Catal. Today 44 (1998) 327-332.

[30] J. S. Hwang, J. S. Chang, S. E. Park, K. Ikeue, M. Anpo, Topics Catal. 35 (2005) 311-319.

[31] C. C. Yang, J. Vernimmen, V. Meynen, P. Cool, G. Mul, J. Catal. 284 (2011) 1-8.

[32] W. Lin, H. Han, H. Frei, J. Phys. Chem. B 108 (2004) 18269-18273.

[33] P. Salvador, J. Appl. Phys. 55 (1984) 2977-2985. 
[34] L. Dloczik, O. Ileperuma, I. Lauermann, L. M. Peter, E. A. Ponomarev, G. Redmond, N. J. Shaw, I. Uhlendorf, J. Phys. Chem. B 101 (1997) 10281-10289.

[35] X. Feng, J. D. Sloppy, T. J. LaTempa, M. Paulose, S. Komarneni, N. Bao, C. A. Grimes, J. Mater. Chem. 21 (2011) 13429-13433.

[36] Y. Izumi, T. Itoi, S. Peng, K. Oka, Y. Shibata, J. Phys. Chem. C 113 (2009) 6706-6718.

[37] Q. Zhang, Y. Li, E. A. Ackerman, M. Gajdardziska-Josifovska, H. Li, Appl. Catal. A 400 (2011) 195-202.

[38] C. C. Yang, Y. H. Yu, B. van der Linden, J. C. S. Wu, G. Mul, J. Am. Chem. Soc. 132 (2010) 8398-8406.

[39] T. Yui, A. Kan, C. Saitoh, K. Koike, T. Ibusuki, O. Ishitani, Appl. Mater. Interfaces 3 (2011) 2594-2600.

[40] Z. Zhao, J. Fan, M. Xie, Z. Wang, J. Cleaner Prod. 17 (2009) 1025-1029.

[41] Z. H. Zhao, J. M. Fan, Z. Z. Wang, J. Cleaner Prod. 15 (2007) 1894-1897.

[42] I. H. Tseng, W. C. Chang, J. C. S. Wu, Appl. Catal. B 37 (2002) 37-48.

[43] I. H. Tseng, J. C. S. Wu, H. Y. Chou, J. Catal. 221 (2004) 432-440.

[44] D. Luo, C. Chen, N. Zhang, S. Hong, H. Wu, Z. Liu, Zeit. Phys. Chem. 223 (2009) $1465-1476$.

[45] X. H. Xia, Z. J. Jia, Y. Yu, Y. Liang, Z. Wang, L. L. Ma, Carbon 45 (2007) 717-721.

[46] A. Danon, P. C. Stair, E. Weitz, Catal. Lett. 141 (2011) 1057-1066.

[47] P. Praus, O. Kozák, K. Kočí, A. Panáček, R. Dvorský, J. Colloid Interface Sci. 360 (2011) $574-579$

[48] R. L. Cook, R. C. MacDuff, A. F. Sammells, J. Electrochem. Soc. 135 (1988) 3069-3070.

[49] P. W. Pan, Y. W. Chen, Catal. Commun. 8 (2007) 1546-1549.

[50] P. Y. Liou, S. C. Chen, J. C. S. Wu, D. Liu, S. Mackintosh, M. Maroto-Valer, R. Linforth, Energy Environ. Sci. 4 (2011) 1487-1494.

[51] D. S. Lee, H. J. Chen, Y. W. Chen, J. Phys. Chem. Solid 73 (2012) 661-669. 
[52] X. Li, H. Pan, W. Li, Z. Zhuang, Appl. Catal. A 413/414 (2012) 103-108.

[53] Y. Zhou, Z. Tian, Z. Zhao, Q. Liu, J. Kou, X. Chen, J. Gao, S. Yan, Z. Zou, Appl. Mater. Interfaces 3 (2011) 3594-3601.

[54] P. Li, S. Ouyang, G. Xi, T. Kako, J. Ye, J. Phys. Chem. C, DOI: 10.1021/jp210106b.

[55] Y. Liu, B. Huang, Y. Dai, X. Zhang, X. Qin, M. Jiang, M. H. Whangbo, Catal. Commun. $11(2009)$ 210-213.

[56] J. W. Lekse, M. K. Underwood, J. P. Lewis, C. Matranga, J. Phys. Chem. C 116 (2012) $1865-1872$.

[57] Q. Liu, Y. Zhou, J. Kou, X. Chen, Z. Tian, J. Gao, S. Yan, Z. Zou, J. Am. Chem. Soc. 132 (2010) 14385-14387.

[58] N. Zhang, S. Ouyang, T. Kako, J. Ye, Chem. Comm. 48 (2012) 1269-1271.

[59] A. Kudo, Y. Miseki, Chem. Soc. Rev. 38 (2009) 253-278.

[60] K. Iizuka, T. Wato, Y. Miseki, K. Saito, A. Kudo, J. Am. Chem. Soc. 133 (2011) 20863-20868.

[61] C. Wang, Z. Xie, K. E. deKrafft, W. Lin, J. Am. Chem. Soc. 133 (2011) 13445-13454.

[62] H. Fujiwara, H. Hosokawa, K. Murakoshi, Y. Wada, S. Yanagida, Langmuir 14 (1998) $5154-5159$

[63] S. Kuwabata, K. Nishida, R. Tsuda, H. Inoue, H. Yoneyama, J. Electrochem. Soc. 141 (1994) 1498-1503.

[64] H. Fujiwara, H. Hosokawa, K. Murakoshi, Y. Wada, S. Yanagida, T. Okada, H. Kobayashi, J. Phys. Chem. B 101 (1997) 8270-8278.

[65] B. J. Liu, T. Torimoto, H. Yoneyama, J. Photochem. Photobio. A: Chem. 113 (1998) 93-97.

[66] Á. Valdés, Z. W. Qu, G. J. Kroes, J. Rossmeisl, J. K. Nørskov, J. Phys. Chem. C 112 (2008) 9872-9879.

[67] L. Cao, S. Sahu, P. Anilkumar, C. E. Bunker, J. Xu, K. A. S. Fernando, P. Wang, E. A. 
Guliants, K. N. Tackett, II, Y. P. Sun, J. Am. Chem. Soc. 133 (2011) 4754-4757.

[68] G. Dong, L. Zhang, J. Mater. Chem. 22 (2012) 1160-1166.

[69] Y. T. Liang, B. K. Vijayan, K. A. Gray, M. C. Hersam, Nano Lett. 11 (2011) 2865-2870.

[70] X. Chen, L. Liu, P. Y. Yu, S. S. Mao, Science 331 (2011) 746-750.

[71] A. Danon, K. Bhattacharyya, B. K. Vijayan, J. Lu, D. J. Sauter, K. A. Gray, P. C. Stair, E. Weitz, ACS Catalysis 2 (2012) 45-49.

[72] D. Masih, H. Yoshitake, Y. Izumi, Appl. Catal. A 325 (2007) 276 - 282.

[73] Y. Izumi, K. Konishi, H. Yoshitake, Bull. Chem. Soc. Jpn. 81 (2008) 1241-1249.

[74] Y. Izumi, K. Konishi, D. Obaid, T. Miyajima, H. Yoshitake, Anal. Chem. 79 (2007) 6933-6940.

[75] K. Maeda, K. Teramura, D. Lu, T. Takata, N. Saito, Y. Inoue, K. Domen, Nature 440 (2006) 295.

[76] M. G. Walter, E. L. Warren, J. R. McKone, S. W. Boettcher, Q. Mi, E. A. Santori, N. S. Lewis, Chem. Rev. 110 (2010) 6446-6473.

[77] K. R. Thampi, J. Kiwi, M. Grätzel, Nature 327 (1987) 506-508.

[78] J. Melsheimer, W. Guo, D. Ziegler, M. Wesemann, R. Schlögl, Catal. Lett. 11 (1991) $157-168$

[79] Y. Kohno, H. Hayashi, S. Takenaka, T. Tanaka, T. Funabiki, S. Yoshida, J. Photochem. Photobiol. A 12 (1999) 117-123.

[80] Y. Kohno, T. Tanaka, T. Funabiki, S. Yoshida, Chem. Commun. (1997) 841-842.

[81] K. Teramura, T. Tanaka, H. Ishikawa, Y. Kohno, T. Funabiki, J. Phys. Chem. B 108 (2004) 346-354.

[82] K. Teramura, H. Tsuneoka, T. Shishido, T. Tanaka, Chem. Phys. Lett. 467 (2008) $191-194$.

[83] C. C. Lo, C. H. Hung, C. S. Yuan, J. F. Wu, Sol. Energy Mater. Sol. Cells 91 (2007) $1765-1774$. 
[84] F. Cavani, F. Trifirò, A. Vaccari, Catal. Today 11 (1991) 173-301.

[85] Y. Izumi, F. Kiyotaki, T. Minato, Y. Seida, Anal. Chem. 74 (2002) 3819-3823.

[86] Y. Izumi, F. Kiyotaki, Y. Seida, J. Phys. Chem. B 106 (2002) 1518-1520.

[87] C. G. Silva, Y. Bouizi, V. Fornés, H. García, J. Am. Chem. Soc. 131 (2009) 13833-13839.

[88] J. L. Gunjakar, T. W. Kim, H. N. Kim, I. Y. Kim, S. J. Hwang, J. Am. Chem. Soc. 133 (2011) 14998-15007.

[89] N. Ahmed, M. Morikawa, Y. Izumi, manuscript in preparation.

[90] R. D. Richardson, E. J. Holland, B. K. Carpenter, Nature Chem. 3 (2011) 301-303.

[91] Q. Yin, J. M. Tan, C. Besson, Y. V. Geletii, D. G. Musaev, A. E. Kuznetsov, Z. Luo, K. I. Hardcastle, C. L. Hill, Science 328 (2010) 342-345.

[92] D. K. Zhong, D. R. Gamelin, J. Am. Chem. Soc. 132 (2010) 4202-4207.

[93] R. F. Service, Science 325 (2009) 1200-1201.

[94] B. Seger, P. V. Kamat, J. Phys. Chem. C 113 (2009) 18946-18952.

[95] D. Voet, J. G. Voet, Biochemistry $2^{\text {nd }}$ Ed., John Wiley \& Sons, 1995, New York, USA, 1995, p.639.

[96] C. Leygraf, M. Hendewerk, G. A. Somorjai, J. Phys. Chem. 86 (1982) 4484-4485.

[97] K. Sayama, K. Mukasa, R. Abe, Y. Abe, H. Arakawa, Chem. Commun. 35 (2001) $2416-2417$.

[98] K. Fujihara, T. Ohno, M. Matsumura, J. Chem. Soc., Faraday Trans. 94 (1998) $3705-3709$.

[99] C. D. Windle, R. N. Perutz, Coord. Chem. Rev., under review.

[100] M. Morikawa, N. Ahmed, Y. Ogura, Y. Izumi, Appl. Catal. B 117/118 (2012) 317-320.

[101] I. A. Shkrob, T. W. Marin, H. He, P. Zapol, J. Phys. Chem. C, DOI: 10.1021/jp300122v.

[102] V. P. Indrakanti, J. D. Kubicki, H. H. Schobert, Energy Environ. Sci. 2 (2009) $7345-758$. 
Table 1. (A) Reported $\mathrm{CO}_{2}$ photoreduction catalysts, reaction conditions, and the formation rates in water/with moisture using $\mathrm{TiO}_{2}$.

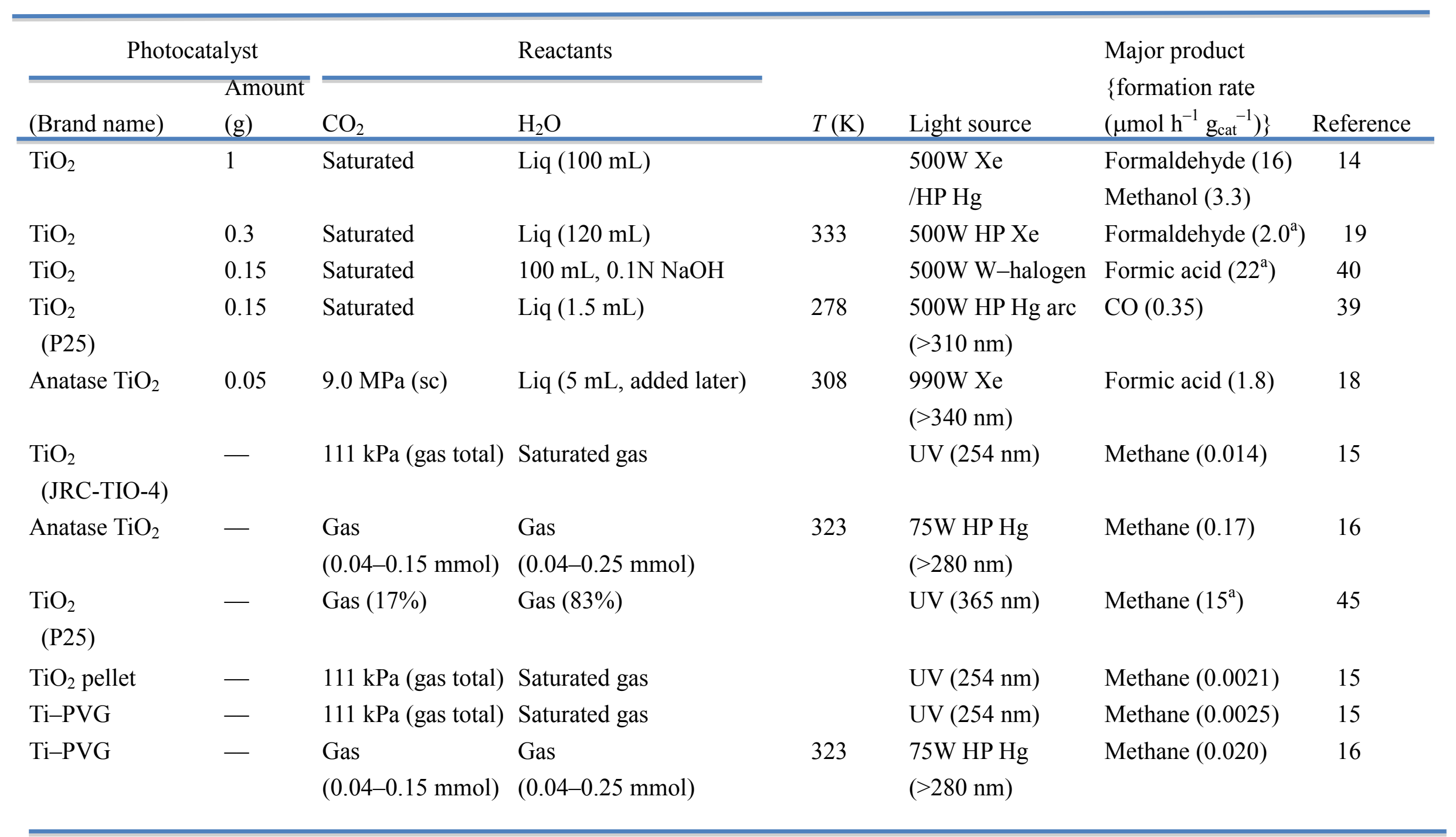

a Spectroscopic verification of reaction route, isotope tracing to identify the C source, or sufficient control kinetic tests to verify the photocatalytic event is required. 
Table 1. (B) Reported $\mathrm{CO}_{2}$ photoreduction catalysts, reaction conditions, and the formation rates in water/with moisture using metal-loaded, highly-dispersed, and modified $\mathrm{TiO}_{2}$.

\begin{tabular}{|c|c|c|c|c|c|c|c|}
\hline \multicolumn{2}{|c|}{ Photocatalyst } & \multicolumn{2}{|r|}{ Reactants } & \multirow[b]{2}{*}{$T(\mathrm{~K})$} & \multirow[b]{2}{*}{ Light source } & \multirow{2}{*}{$\begin{array}{l}\text { Major product } \\
\{\text { formation rate } \\
\left.\left(\mu \mathrm{mol} \mathrm{h}{ }^{-1} \mathrm{~g}_{\text {cat }}^{-1}\right)\right\}\end{array}$} & \multirow[b]{2}{*}{ Reference } \\
\hline (Brand name) & $\begin{array}{l}\text { Amount } \\
(\mathrm{g})\end{array}$ & $\mathrm{CO}_{2}$ & $\mathrm{H}_{2} \mathrm{O}$ & & & & \\
\hline $\mathrm{TiO}_{2}-\mathrm{MWCNT}$ & - & Gas (17\%) & $\operatorname{Gas}(83 \%)$ & & UV (365 nm) & $\begin{array}{l}\text { Ethanol }\left(30^{\mathrm{a}}\right), \\
\text { Formic acid }\left(19^{\mathrm{a}}\right) \text {, } \\
\text { Methane }\left(12^{\mathrm{a}}\right)\end{array}$ & 45 \\
\hline Ti-Y-zeolite & 0.15 & Gas $(24 \mu \mathrm{mol})$ & Gas $(120 \mu \mathrm{mol})$ & 328 & HP Hg $(>280 \mathrm{~nm})$ & $\begin{array}{l}\text { Methane }(0.046) \\
\text { Methanol }(0.031)\end{array}$ & 28 \\
\hline Pt-Ti-Y-zeolite & 0.15 & Gas $(24 \mu \mathrm{mol})$ & Gas $(120 \mu \mathrm{mol})$ & 328 & $\mathrm{HP} \mathrm{Hg}(>280 \mathrm{~nm})$ & Methane (0.080) & 28 \\
\hline $\begin{array}{r}\mathrm{Ti}-\mathrm{MCM}-48 \\
(\mathrm{Si} / \mathrm{Ti}=80)\end{array}$ & - & Gas $(24 \mu \mathrm{mol})$ & Gas $(120 \mu \mathrm{mol})$ & 328 & HP Hg $(>280 \mathrm{~nm})$ & $\begin{array}{l}\text { Methane (7.5), } \\
\text { Methanol (3.1) }\end{array}$ & 29 \\
\hline $\begin{array}{l}\text { Pt-Ti-MCM-48 } \\
(1.0 \mathrm{wt} \% \mathrm{Pt}, \mathrm{Si} / \mathrm{T}\end{array}$ & $\begin{array}{l}- \\
i=80)\end{array}$ & Gas $(24 \mu \mathrm{mol})$ & Gas $(120 \mu \mathrm{mol})$ & 328 & HP Hg $(>280 \mathrm{~nm})$ & Methane (12) & 29 \\
\hline $\begin{array}{l}\text { Ti-SBA-15 } \\
(0.29 \text { wt } \% \text { Ti, Si }\end{array}$ & $\begin{array}{l}0.05 \\
\Gamma i=270)\end{array}$ & Gas $(36 \mu \mathrm{mol})$ & Gas $(180 \mu \mathrm{mol})$ & 323 & $\begin{array}{l}100 \mathrm{~W} \mathrm{HP} \mathrm{Hg} \\
(>250 \mathrm{~nm})\end{array}$ & $\begin{array}{l}\text { Methane }(0.31) \\
\text { Methanol }(0.081)\end{array}$ & 30 \\
\hline $\begin{array}{l}\text { Ti-SBA-15 } \\
(0.05 \mathrm{wt} \% \mathrm{Ti})\end{array}$ & 0.05 & Gas $(38 \mu \mathrm{mol})$ & Gas $(76 \mu \mathrm{mol})$ & 313 & 120W HP Hg & $\begin{array}{l}\text { Ethane }(0.020), \\
\text { Methane }(0.016), \\
\text { Ethene }(0.007)\end{array}$ & 31 \\
\hline
\end{tabular}

\footnotetext{
a Spectroscopic verification of reaction route, isotope tracing to identify the $\mathrm{C}$ source, or sufficient control kinetic tests to verify the photocatalytic event is required.
} 
Table 1. (B) (continued)

\begin{tabular}{|c|c|c|c|c|c|c|c|}
\hline \multicolumn{2}{|c|}{ Photocatalyst } & \multicolumn{2}{|r|}{ Reactants } & \multirow[b]{2}{*}{$T(\mathrm{~K})$} & \multirow[b]{2}{*}{ Light source } & \multirow{2}{*}{$\begin{array}{l}\text { Major product } \\
\{\text { formation rate } \\
\left.\left(\mu \mathrm{mol} \mathrm{h}{ }^{-1} \mathrm{~g}_{\text {cat }}^{-1}\right)\right\}\end{array}$} & \multirow[b]{2}{*}{ Reference } \\
\hline (Brand name) & $\begin{array}{l}\text { Amount } \\
\text { (g) }\end{array}$ & $\mathrm{CO}_{2}$ & $\mathrm{H}_{2} \mathrm{O}$ & & & & \\
\hline $\mathrm{CdSe}-\mathrm{Pt} / \mathrm{TiO}_{2}$ & 0.3 & Gas $(40 \mathrm{~Pa})$ & Gas (400 Pa) & & $\begin{array}{l}300 \mathrm{~W} \mathrm{Xe} \\
(>420 \mathrm{~nm})\end{array}$ & Methane, Methanol & 26 \\
\hline $\mathrm{PbS}-\mathrm{Cu} / \mathrm{TiO}_{2}$ & & Gas & Saturated gas & & $\begin{array}{l}300 \mathrm{~W} \text { Xe } \\
\text { (UV cut) }\end{array}$ & $\begin{array}{l}\text { CO }(0.82), \\
\text { Methane }(0.58)\end{array}$ & 27 \\
\hline $\begin{array}{c}\mathrm{Rh}(1 \mathrm{wt} \%) / \mathrm{WO}_{3} \\
(2 \mathrm{wt} \%)-\mathrm{TiO}_{2}\end{array}$ & 0.3 & Saturated & Liq $(120 \mathrm{~mL})$ & 333 & 500W HP Xe & Formic acid $\left(1.6^{\mathrm{a}}\right)$ & 19 \\
\hline $\begin{array}{l}\mathrm{Rh} / \mathrm{WO}_{3}-\mathrm{TiO}_{2} \\
\text {-reduced }\end{array}$ & 0.3 & Saturated & Liq $(120 \mathrm{~mL})$ & 333 & 500W HP Xe & Methanol $\left(4.0^{\mathrm{a}}\right)$ & 19 \\
\hline $\begin{array}{l}\mathrm{Co}{ }^{\mathrm{II}}-\mathrm{Pc}(0.7 \mathrm{wt} \%) \\
/ \mathrm{TiO}_{2}\end{array}$ & 0.15 & Saturated & $100 \mathrm{~mL}, 0.1 \mathrm{~N} \mathrm{NaOH}$ & & 500W W-halogen & Formic acid $\left(150^{\mathrm{a}}\right)$ & 40 \\
\hline $\begin{array}{l}\mathrm{Zn}{ }^{\mathrm{II}}-\mathrm{Pc}(1 \mathrm{wt} \%) \\
/ \mathrm{TiO}_{2}\end{array}$ & 0.15 & Saturated (2.3 g) & $100 \mathrm{~mL}, 0.1 \mathrm{~N} \mathrm{NaOH}$ & & 500W W-halogen & Formic acid $\left(98^{\mathrm{a}}\right)$ & 41 \\
\hline $\begin{array}{l}\mathrm{Nd}^{\mathrm{III}}(0.2 \mathrm{wt} \%) \\
/ \mathrm{TiO}_{2}\end{array}$ & - & Saturated & Liq & & UV & Methanol $\left(23^{\mathrm{a}}\right)$ & 44 \\
\hline $\mathrm{Pd}(1 \mathrm{wt} \%)-\mathrm{TiO}_{2}$ & 0.15 & Saturated & Liq $(1.5 \mathrm{~mL})$ & 278 & $\begin{array}{l}\text { 500W HP Hg arc } \\
(>310 \mathrm{~nm})\end{array}$ & Methane (0.37) & 39 \\
\hline $\mathrm{Cu}-\mathrm{TiO}_{2}$ & $0.15-0.6$ & Saturated & $300 \mathrm{~mL}, 0.2 \mathrm{~N} \mathrm{NaOH}$ & 323 & $\mathrm{Hg}(254 \mathrm{~nm})$ & Methanol $\left(20^{\mathrm{a}}\right)$ & 42,43 \\
\hline
\end{tabular}


Table 1. (B) (continued)

\begin{tabular}{|c|c|c|c|c|c|c|c|}
\hline \multicolumn{2}{|c|}{ Photocatalyst } & \multicolumn{2}{|r|}{ Reactants } & \multirow[b]{2}{*}{$T(\mathrm{~K})$} & \multirow[b]{2}{*}{ Light source } & \multirow{2}{*}{$\begin{array}{l}\text { Major product } \\
\{\text { formation rate } \\
\left.\left(\mu \mathrm{mol} \mathrm{h}{ }^{-1} \mathrm{~g}_{\mathrm{cat}}^{-1}\right)\right\}\end{array}$} & \multirow[b]{2}{*}{ Reference } \\
\hline (Brand name) & $\begin{array}{l}\text { Amount } \\
\text { (g) }\end{array}$ & $\mathrm{CO}_{2}$ & $\mathrm{H}_{2} \mathrm{O}$ & & & & \\
\hline $\mathrm{Cu}-\mathrm{N}-\mathrm{TiO}_{2} \mathrm{NT}$ & - & $108 \mathrm{kPa}$ (gas total) & Saturated & 317 & Sun & Methane (4.4) & 13 \\
\hline $\mathrm{Cu}-\mathrm{N}-\mathrm{TiO}_{2} \mathrm{NT}$ & - & $108 \mathrm{kPa}$ (gas total) & Saturated & 317 & No light & Methane $\left(0.13^{\mathrm{a}}\right)$ & 13 \\
\hline $\mathrm{Pt}-\mathrm{N}-\mathrm{TiO}_{2} \mathrm{NT}$ & - & $108 \mathrm{kPa}$ (gas total) & Saturated & 317 & Sun & Methane (2.9) & 13 \\
\hline No catalyst & 0 & $108 \mathrm{kPa}$ (gas total) & Saturated & 317 & Sun & Methane $\left(0.10^{\mathrm{a}}\right)$ & 13 \\
\hline $\mathrm{I}-\mathrm{TiO}_{2}$ & 0.2 & $99 \mathrm{kPa}$ & $2.3 \mathrm{kPa}$ & & $\mathrm{Xe}$ & $\operatorname{CO}\left(2.4^{\mathrm{a}}\right)$ & 37 \\
\hline
\end{tabular}

a Spectroscopic verification of reaction route, isotope tracing to identify the C source, or sufficient control kinetic tests to verify the photocatalytic event is required. 
Table 1. (C) Reported $\mathrm{CO}_{2}$ photoreduction catalysts, reaction conditions, and the formation rates in water/with moisture using semiconductor photoatalysts other than $\mathrm{TiO}_{2}$.

\begin{tabular}{|c|c|c|c|c|c|c|c|}
\hline \multicolumn{2}{|c|}{ Photocatalyst } & \multicolumn{2}{|r|}{ Reactants } & \multirow[b]{2}{*}{$T(\mathrm{~K})$} & \multirow[b]{2}{*}{ Light source } & \multirow{2}{*}{$\begin{array}{l}\text { Major product } \\
\{\text { formation rate } \\
\left.\left(\mu \mathrm{mol} \mathrm{h}{ }^{-1} \mathrm{~g}_{\text {cat }}^{-1}\right)\right\}\end{array}$} & \multirow[b]{2}{*}{ Reference } \\
\hline (Brand name) & $\begin{array}{l}\text { Amount } \\
(\mathrm{g})\end{array}$ & $\mathrm{CO}_{2}$ & $\mathrm{H}_{2} \mathrm{O}$ & & & & \\
\hline \multirow[t]{2}{*}{$\mathrm{ZnO}$} & 1 & Saturated & Liq (100 mL) & & 500W Xe & Formaldehyde (17) & 14 \\
\hline & & & & & /HP Hg & Methanol (5.0) & \\
\hline \multirow[t]{2}{*}{$\mathrm{CdS}$} & 1 & Saturated & Liq $(100$ mL) & & $500 \mathrm{~W} \mathrm{Xe}$ & Formaldehyde (29) & 14 \\
\hline & & & & & /HP Hg & Methanol (17) & \\
\hline \multirow[t]{2}{*}{$\mathrm{GaP}$} & 1 & Saturated & Liq $(100 \mathrm{~mL})$ & & $500 \mathrm{~W}$ Xe & Formaldehyde (14) & 14 \\
\hline & & & & & /HP Hg & Methanol (16) & \\
\hline \multirow[t]{2}{*}{$\mathrm{SiC}$} & 1 & Saturated & Liq $(100$ mL) & & $500 \mathrm{~W}$ Xe & Formaldehyde (14) & 14 \\
\hline & & & & & /HP Hg & Methanol (76) & \\
\hline $\begin{array}{l}\text { CdS- } \\
\text { montmorillonite }\end{array}$ & $1 \mathrm{~g} / \mathrm{L}$ & Saturated & $0.2 \mathrm{mM} \mathrm{NaOH}$ & & $8 \mathrm{~W} \mathrm{Hg}$ & Methane (0.93) & 47 \\
\hline $\mathrm{Cu}-\mathrm{p}-\mathrm{SiC}$ & 0.10 & Saturated & $0.5 \mathrm{M} \mathrm{KHCO}_{3}$ & 313 & $\mathrm{Hg}(>275 \mathrm{~nm})$ & Methane (0.63) & 48 \\
\hline $\begin{array}{l}\mathrm{NiO}(1.0 \mathrm{wt} \%) \\
/ \mathrm{InTaO}_{4}\end{array}$ & 0.14 & Saturated & $0.2 \mathrm{M} \mathrm{KHCO}_{3}$ & & 500W halogen & Methanol $\left(1.4^{\mathrm{a}}\right)$ & 49 \\
\hline $\begin{array}{l}\mathrm{NiO}(2.6 \mathrm{wt} \%) \\
/ \mathrm{InTaO}_{4}\end{array}$ & & Gas & Gas & 303 & $300 \mathrm{~W} \mathrm{Xe}$ & Acetaldehyde $\left(0.21^{\mathrm{a}}\right)$ & 50 \\
\hline $\mathrm{BiWO}_{6}$ & 0.1 & Saturated & $1 \mathrm{~mL}$ & & $\begin{array}{l}\text { 300W Xe arc } \\
(>420 \mathrm{~nm})\end{array}$ & Methane (1.1) & 53 \\
\hline
\end{tabular}

a Spectroscopic verification of reaction route, isotope tracing to identify the C source, or sufficient control kinetic tests to verify the photocatalytic event is required. 
Table 1. (C) (continued)

\begin{tabular}{|c|c|c|c|c|c|c|c|}
\hline \multicolumn{2}{|c|}{ Photocatalyst } & \multicolumn{2}{|r|}{ Reactants } & $T(\mathrm{~K})$ & Light source & $\begin{array}{l}\text { Major product } \\
\{\text { formation rate } \\
\left.\left(\text { umol h}^{-1} \mathrm{~g}_{\text {cat }}^{-1}\right)\right\}\end{array}$ & Reference \\
\hline $\mathrm{BiVO}_{4}$, monoclinic & 0.20 & Saturated & $100 \mathrm{~mL}$ & 273 & $\begin{array}{l}\text { 300W Xe arc } \\
(>400 \mathrm{~nm})\end{array}$ & Ethanol $\left(110^{\mathrm{a}}\right)$ & 55 \\
\hline $\mathrm{Pt}-\mathrm{NaNbO}_{3}$ & 0.1 & Gas $(80 \mathrm{kPa})$ & $3 \mathrm{~mL}$ & & $300 \mathrm{~W}$ Xe arc & Methane (4.9) & 54 \\
\hline $\mathrm{Zn}_{2} \mathrm{GeO}_{4}$ & - & Gas & Gas & & Light & Methane $(0.41)$ & 57 \\
\hline $\mathrm{RuO}_{2}-\mathrm{Zn}_{2} \mathrm{GeO}_{4}$ & - & Gas & Gas & & Light & Methane (1.9) & 57 \\
\hline $\mathrm{RuO}_{2}-\mathrm{Pt}-\mathrm{Zn}_{2} \mathrm{GeO}$ & - & Gas & Gas & & Light & Methane (6.5) & 57 \\
\hline
\end{tabular}


Table 1. (C) (continued)

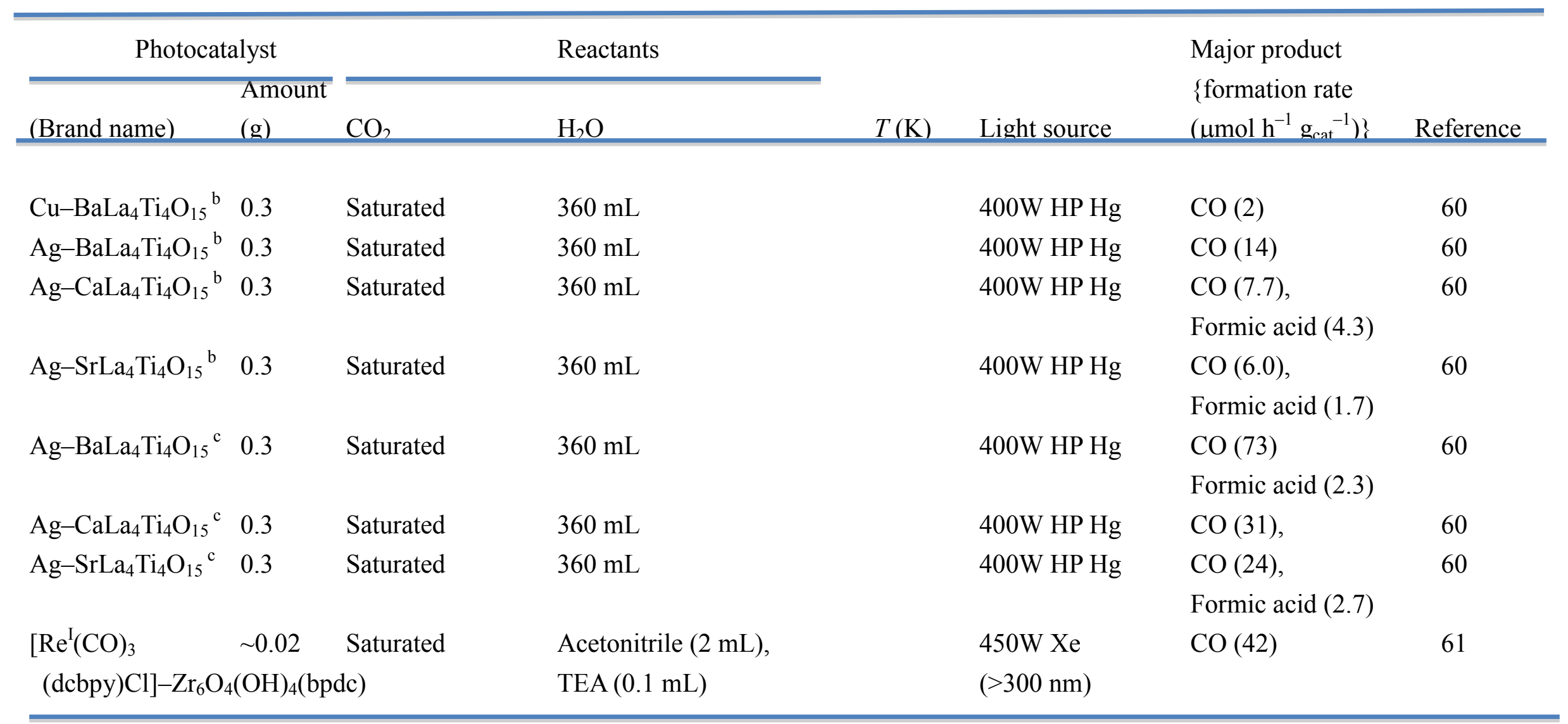

b $\mathrm{Cu}$ or Ag was photodeposited during catalyst preparation.

c Ag was reduced in liquid phase during catalyst preparation. 
Table 2. Reported $\mathrm{CO}_{2}$ photoreduction catalysts, reaction conditions, and the formation rates with hydrogen [and moisture].

\begin{tabular}{|c|c|c|c|c|c|c|c|c|}
\hline \multicolumn{2}{|c|}{ Photocatalyst } & \multicolumn{3}{|c|}{ Reactants (gas) } & \multirow[b]{2}{*}{$T(\mathrm{~K})$} & \multirow[b]{2}{*}{ Light source } & \multirow{2}{*}{$\begin{array}{l}\text { Major product } \\
\{\text { formation rate } \\
\left.\left(\mu \mathrm{mol} \mathrm{h}{ }^{-1} \mathrm{~g}_{\text {cat }}^{-1}\right)\right\}\end{array}$} & \multirow[b]{2}{*}{ Reference } \\
\hline (Brand name) & $\begin{array}{l}\text { Amount } \\
(\mathrm{g})\end{array}$ & $\mathrm{CO}_{2}$ & $\mathrm{H}_{2} \mathrm{O}$ & $\mathrm{H}_{2}$ & & & & \\
\hline $\mathrm{Ru} / \mathrm{RuO}_{x} / \mathrm{TiO}_{2}$ & 0.1 & $5.1 \mathrm{kPa}$ & & $61 \mathrm{kPa}$ & 319 & Solar simulator & Methane (49) & $77^{\mathrm{a}}$ \\
\hline $\mathrm{Rh} / \mathrm{TiO}_{2}$ & 0.3 & $150 \mu \mathrm{mol}$ & & $50 \mu \mathrm{mol}$ & & 500W HP Hg & $\mathrm{CO}(5.1)$ & 79 \\
\hline $\mathrm{ZrO}_{2}$ & 0.3 & $150 \mu \mathrm{mol}$ & & $50 \mu \mathrm{mol}$ & & 500W HP Hg & $\mathrm{CO}(0.56)$ & 80 \\
\hline $\mathrm{MgO}$ & 0.3 & $150 \mu \mathrm{mol}$ & & $50 \mu \mathrm{mol}$ & & 500W HP Hg & $\mathrm{CO}(1.6)$ & 81 \\
\hline$\beta-\mathrm{Ga}_{2} \mathrm{O}_{3}$ & 1.0 & $150 \mu \mathrm{mol}$ & & $50 \mu \mathrm{mol}$ & & $200 \mathrm{~W} \mathrm{Hg}-\mathrm{Xe}$ & $\mathrm{CO}(0.76)$ & 82 \\
\hline $\mathrm{TiO}_{2}$ & 0.25 & $5.6 \mathrm{kPa}$ & $5.6 \mathrm{kPa}$ & $100 \mathrm{kPa}$ & & UV (365 nm) & Methane (4.1) & 83 \\
\hline $\mathrm{ZrO}_{2}$ & 0.25 & $5.6 \mathrm{kPa}$ & & $106 \mathrm{kPa}$ & & UV (254 nm) & $\mathrm{CO}(0.62)$ & 83 \\
\hline $\begin{array}{l}\text { Ti-SBA-15 } \\
(0.05 \mathrm{wt} \% \text { Ti })\end{array}$ & 0.05 & $38 \mu \mathrm{mol}$ & & $76 \mu \mathrm{mol}$ & 313 & 120W HP Hg & $\begin{array}{l}\text { Methane }(0.012) \text {, } \\
\text { Ethene }(0.008), \\
\text { Ethane }(0.005)\end{array}$ & 31 \\
\hline $\begin{array}{r}{\left[\mathrm{Zn}_{3} \mathrm{Al}(\mathrm{OH})_{8}\right]_{2}^{+}} \\
\left(\mathrm{CO}_{3}\right)^{2-} \cdot m \mathrm{H}_{2} \mathrm{O}\end{array}$ & 0.10 & $\begin{array}{l}2.3 \mathrm{kPa} \\
(0.18 \mathrm{mmol})\end{array}$ & & $\begin{array}{l}22 \mathrm{kPa} \\
(1.7 \mathrm{mmo}\end{array}$ & 1) & $\begin{array}{l}500 \mathrm{~W} X \mathrm{Xe} \text { arc } \\
\left(42 \mathrm{~mW} \mathrm{~cm}^{-2}\right)\end{array}$ & $\begin{array}{l}\text { CO }(0.62) \\
\text { Methanol }(0.039)\end{array}$ & 3 \\
\hline $\begin{array}{l}{\left[\mathrm{Zn}_{1.5} \mathrm{Cu}_{1.5} \mathrm{Al}\right.} \\
\left.\quad(\mathrm{OH})_{8}\right]_{2}^{+}\left(\mathrm{CO}_{3}\right)^{2-}\end{array}$ & $\begin{array}{r}0.10 \\
m \mathrm{H}_{2} \mathrm{O}\end{array}$ & $2.3 \mathrm{kPa}$ & & $22 \mathrm{kPa}$ & $305-313$ & $\begin{array}{l}500 \mathrm{~W} \text { Xe arc } \\
\left(42 \mathrm{~mW} \mathrm{~cm}^{-2}\right)\end{array}$ & $\begin{array}{l}\text { CO }(0.37) \\
\text { Methanol }(0.13)\end{array}$ & 3 \\
\hline $\begin{array}{l}{\left[\mathrm{Zn}_{1.5} \mathrm{Cu}_{1.5} \mathrm{Al}\right.} \\
\left.\quad(\mathrm{OH})_{8}\right]_{2}^{+}\left(\mathrm{CO}_{3}\right)^{2-}\end{array}$ & $\begin{array}{r}0.10 \\
m \mathrm{H}_{2} \mathrm{O}\end{array}$ & $2.3 \mathrm{kPa}$ & & $22 \mathrm{kPa}$ & $305-313$ & $\begin{array}{l}\text { 500W Xe arc } \\
\left(106 \mathrm{~mW} \mathrm{~cm}^{-2}\right)\end{array}$ & $\begin{array}{l}\text { CO }(0.58) \text {, } \\
\text { Methanol }(0.20)\end{array}$ & 3 \\
\hline
\end{tabular}

a Sufficient control kinetic tests to deny the photocatalytic event were reported in reference 78. 
Table 2. (continued)

\begin{tabular}{|c|c|c|c|c|c|c|c|c|}
\hline \multicolumn{2}{|c|}{ Photocatalyst } & \multicolumn{3}{|c|}{ Reactants (gas) } & \multirow[b]{2}{*}{$T(\mathrm{~K})$} & \multirow[b]{2}{*}{ Light source } & \multirow{2}{*}{$\begin{array}{l}\text { Major product } \\
\{\text { formation rate } \\
\left.\left(\text { umol h }^{-1} \mathrm{~g}_{\text {cat }}^{-1}\right)\right\}\end{array}$} & \multirow[b]{2}{*}{ Reference } \\
\hline (Brand name) & $\begin{array}{l}\text { Amount } \\
\text { (g) }\end{array}$ & $\mathrm{CO}_{2}$ & $\mathrm{H}_{2} \mathrm{O}$ & $\mathrm{H}_{2}$ & & & & \\
\hline $\begin{array}{c}{\left[\mathrm{Zn}_{3} \mathrm{Ga}(\mathrm{OH})_{8}\right]_{2}^{+}} \\
\left(\mathrm{CO}_{3}\right)^{2-} \cdot m \mathrm{H}_{2} \mathrm{O}\end{array}$ & 0.10 & $2.3 \mathrm{kPa}$ & & $22 \mathrm{kPa}$ & $305-313$ & $\begin{array}{l}500 \mathrm{~W} X \mathrm{Xe} \text { arc } \\
\left(42 \mathrm{~mW} \mathrm{~cm}^{-2}\right)\end{array}$ & $\begin{array}{l}\text { CO }(0.080), \\
\text { Methanol }(0.051)\end{array}$ & 3 \\
\hline $\begin{array}{l}{\left[\mathrm{Zn}_{1.5} \mathrm{Cu}_{1.5} \mathrm{Ga}\right.} \\
\left.\quad(\mathrm{OH})_{8}\right]_{2}^{+}\left(\mathrm{CO}_{3}\right)^{2-}\end{array}$ & $\begin{array}{c}0.10 \\
m \mathrm{H}_{2} \mathrm{O}\end{array}$ & $2.3 \mathrm{kPa}$ & & $22 \mathrm{kPa}$ & $305-313$ & $\begin{array}{l}500 \mathrm{~W} \mathrm{Xe} \mathrm{arc} \\
\left(42 \mathrm{~mW} \mathrm{~cm}^{-2}\right)\end{array}$ & $\begin{array}{l}\text { Methanol (0.17), } \\
\text { CO }(0.079)\end{array}$ & 3 \\
\hline $\begin{array}{c}{\left[\mathrm{Zn}_{3} \mathrm{Ga}(\mathrm{OH})_{8}\right]_{2}^{+}} \\
{\left[\mathrm{Cu}(\mathrm{OH})_{4}\right]^{2-} \cdot m \mathrm{H}_{2}}\end{array}$ & $\mathrm{O}^{0.10}$ & $2.3 \mathrm{kPa}$ & & $22 \mathrm{kPa}$ & $305-313$ & $\begin{array}{l}500 \mathrm{~W} X \mathrm{arc} \\
\left(42 \mathrm{~mW} \mathrm{~cm}^{-2}\right)\end{array}$ & $\begin{array}{l}\text { Methanol }(0.30) \text {, } \\
\text { CO }(0.13)\end{array}$ & 4 \\
\hline $\begin{array}{l}{\left[\mathrm{Zn}_{1.5} \mathrm{Cu}_{1.5} \mathrm{Ga}\right.} \\
\left.\quad(\mathrm{OH})_{8}\right]_{2}^{+}[\mathrm{Cu}(\mathrm{OH})\end{array}$ & $\begin{array}{l}0.10 \\
4]^{2-} \cdot m \mathrm{H}_{2} \mathrm{O}\end{array}$ & $2.3 \mathrm{kPa}$ & & $22 \mathrm{kPa}$ & $305-313$ & $\begin{array}{l}500 \mathrm{~W} \mathrm{Xe} \mathrm{arc} \\
\left(42 \mathrm{~mW} \mathrm{~cm}^{-2}\right)\end{array}$ & $\begin{array}{l}\text { Methanol (0.49), } \\
\text { CO }(0.070)\end{array}$ & 4 \\
\hline $\mathrm{Cu}-\mathrm{ZnO}$ & 0.10 & $2.3 \mathrm{kPa}$ & & $22 \mathrm{kPa}$ & $305-313$ & $\begin{array}{l}500 \mathrm{~W} X \mathrm{arc} \\
\left(42 \mathrm{~mW} \mathrm{~cm}^{-2}\right)\end{array}$ & $\mathrm{CO}(0.030)$ & 3 \\
\hline$\alpha-\mathrm{Ga}_{2} \mathrm{O}_{3}$ & 0.10 & $2.3 \mathrm{kPa}$ & & $22 \mathrm{kPa}$ & $305-313$ & $\begin{array}{l}500 \mathrm{~W} X \mathrm{Xe} \text { arc } \\
\left(42 \mathrm{~mW} \mathrm{~cm}^{-2}\right)\end{array}$ & $\mathrm{CO}(0.047)$ & 3 \\
\hline
\end{tabular}




\section{Figure Captions}

Figure 1. 2008 Distribution of world energy consumption by source [1].

Figure 2. Comparison of the (100) and (110) crystal faces in the crystal structure of rutile $\mathrm{TiO}_{2}$ and their performance in photocatalytic $\mathrm{CO}_{2}$ reduction [16].

Figure 3. Energy diagram for bulk and nano $\mathrm{CdSe}$ with $\mathrm{TiO}_{2}$, and the redox potentials for the $\mathrm{CO}_{2}$ reduction and water oxidation reaction steps (Reprinted with permission from $\mathrm{C}$. Wang, R. L. Thompson, J. Baltrus, C. Matranga, J. Phys. Chem. Lett. 1 (2010) 48-53 [26]. Copyright (2010) American Chemical Society).

Figure 4. (a) Photograph of the reaction chambers set in the sunlight during summer in Pennsylvania, USA for photocatalytic $\mathrm{CO}_{2}$ conversion under $\mathrm{CO}_{2}$ saturated with moisture (total pressure $<108 \mathrm{kPa}$ ). (b) Spectral irradiation for the photocatalytic tests (Reprinted with permission from O. K. Varghese, M. Paulose, T. J. LaTempa, C. A. Grimes, Nano Lett. 9 (2009) 731-737 [13]. Copyright (2009) American Chemical Society).

Figure 5. Isotope distribution of the adsorbed $\mathrm{CO}\left({ }^{12} \mathrm{CO}\right.$ at $2115 \mathrm{~cm}^{-1}$ and ${ }^{13} \mathrm{CO}$ at 2069 $\mathrm{cm}^{-1}$ ) over $\mathrm{Cu} / \mathrm{TiO}_{2}$ monitored by diffuse reflectance infrared Fourier-transform spectroscopy in ${ }^{13} \mathrm{CO}$ (Reprinted with permission from C. C. Yang, Y. H. Yu, B. van der Linden, J. C. S. Wu, G. Mul, J. Am. Chem. Soc. 132 (2010) 8398-8406 [38]. Copyright (2010) American Chemical Society).

Figure 6. Dependence of the formation rates of methanol and CO on the cut-off wavelength for photoreactions in $\mathrm{CO}_{2}(2.3 \mathrm{kPa})+\mathrm{H}_{2}(22 \mathrm{kPa})$ using $0.10 \mathrm{~g}$ of 
$\left[\mathrm{Zn}_{3} \mathrm{Ga}(\mathrm{OH})_{8}\right]_{2}^{+}\left(\mathrm{CO}_{3}\right)^{2-} \cdot m \mathrm{H}_{2} \mathrm{O}$ or $\left[\mathrm{Zn}_{1.5} \mathrm{Cu}_{1.5} \mathrm{Ga}(\mathrm{OH})_{8}\right]_{2}^{+}\left(\mathrm{CO}_{3}\right)^{2-} \cdot m \mathrm{H}_{2} \mathrm{O}$. Sharp cut-off filters UV-32, L-37, L-42, or Y-48 were used at the exit of the Xe arc lamp. (Inset) In-process spectrum of product formation rates versus wavelength [3].

Figure 7. Quartz photocatalytic reactor illuminated using a Xe arc lamp Model UI-502Q, Ushio (a) and Model SX-UID502XAM, Ushio (b) used in references 3 and 4.

Figure 8. Recyclable photocatalytic $\mathrm{CO}_{2}$ reduction to formic acid using a sacrificial electron donor amine that can be regenerated by hydrogenation using a Pd catalyst (Reprinted by permission from Macmillan Publishers Ltd: Nature Chemistry, J. Michl, 3 (2011) 268-269 [8], copyright (2011)).

Figure 9. Concept of a fuel cell supplied with hydrogen and oxygen (or air) that converts chemical energy to electricity. The solar fuel cell uses light to separate holes and electrons that oxidize water and reduce protons, respectively (N. S. Lewis, D. G. Nocera, Proc. Natl. Acad. Sci. U.S.A. 104 (2007) 20142 [9], Copyright 2007 National Academy of Sciences, U.S.A.).

Figure 10. Dye-sensitized solar cell utilizing a polymer membrane and a manganese catalyst [93] (Copyright permitted by Dr. Gerhard Swiegers, University of Wollongong).

Figure 11. Combination of water oxidation catalyst and the reduction of protons to $\mathrm{H}_{2}$ or $\mathrm{CO}_{2}$ to fuels. The reduction is promoted as a result of charge separation under light irradiation. The reduction catalyst might be assembled on an electrode, a suspension of nanoparticles, or conducting organic or inorganic membranes capable of directing charge transport (From J. K. Hurst, Science 328 (2010) 315-316 [7]. Reprinted with permission from AAAS). 
Figure 12. Feasibility test of a fuel cell consisting of a $\mathrm{TiO}_{2}$ photocatalyst for methanol oxidation, a Pt catalyst for the production of $\mathrm{H}_{2}$, and an $\mathrm{H}^{+}$-conducting polymer between them (Reprinted with permission from B. Seger, P. V. Kamat, J. Phys. Chem. C 113 (2009) 18946-18952 [94]. Copyright (2009) American Chemical Society).

Figure 13. Proposed reaction mechanism using a PEFC starting from $\mathrm{H}_{2}$ and $\mathrm{CO}_{2}$ (a) and from $\mathrm{H}_{2} \mathrm{O}$ and $\mathrm{CO}_{2}$ (b) [100]. 


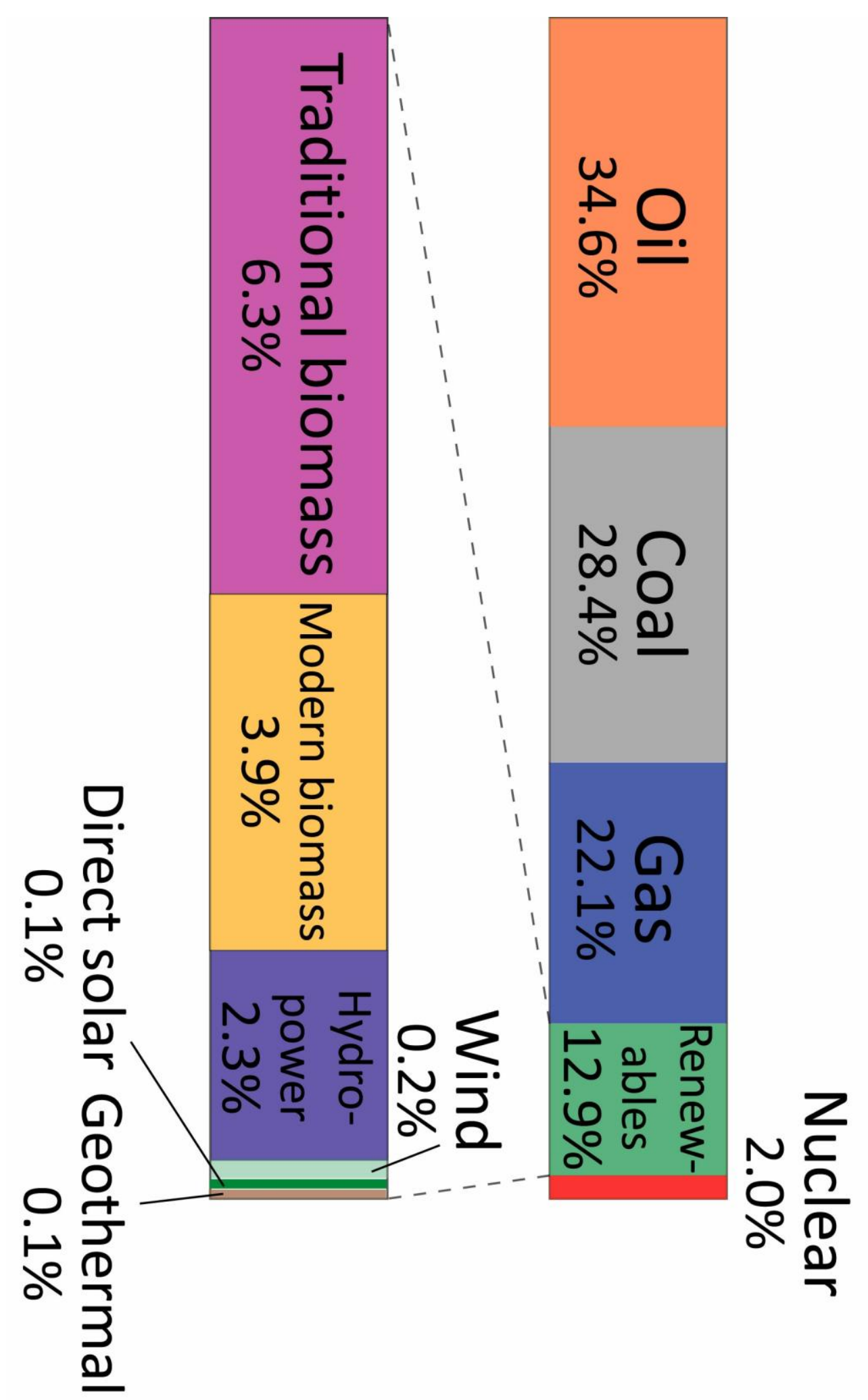

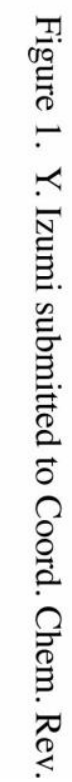




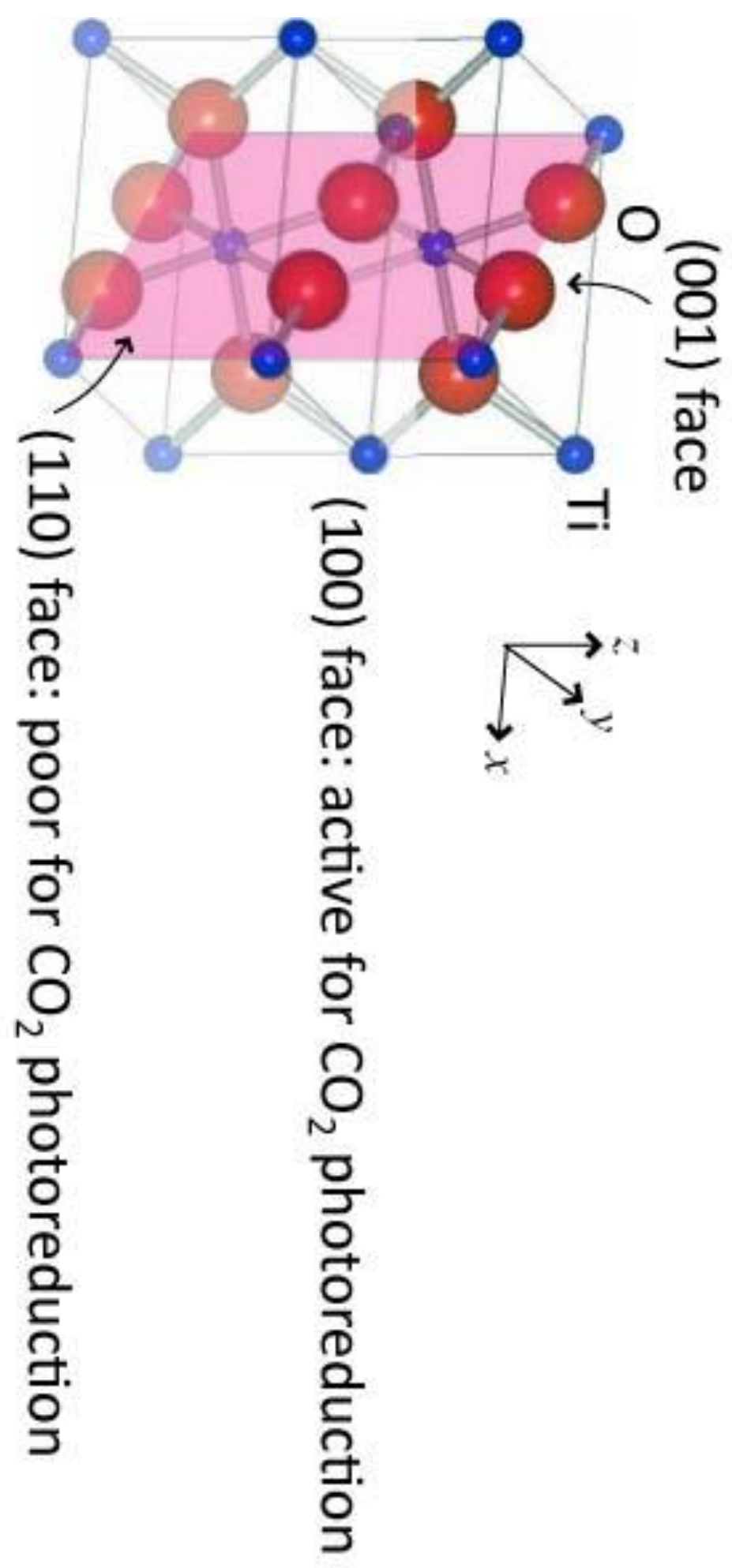

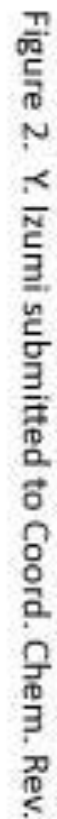


Figure 3.

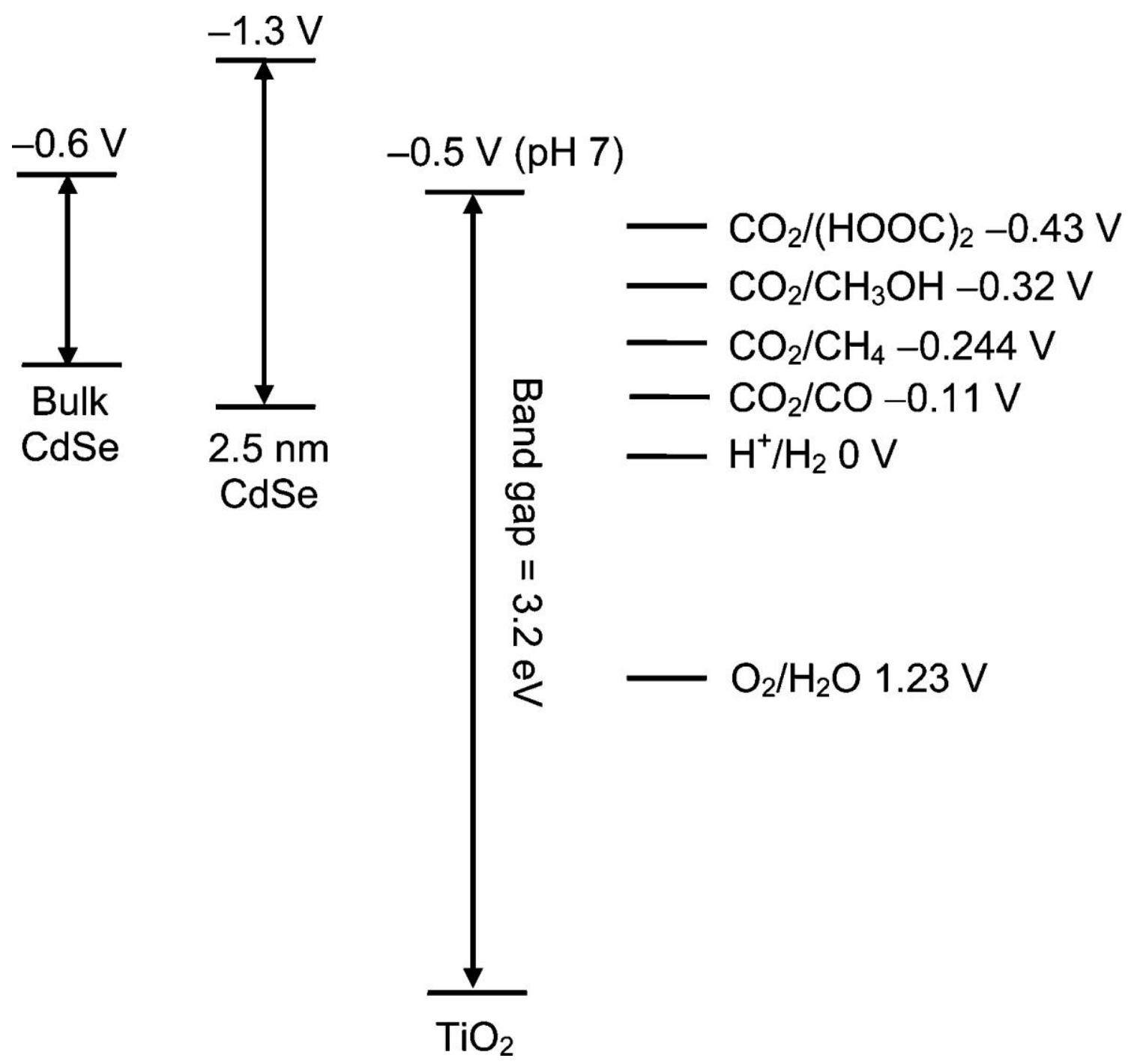


Figure 4.
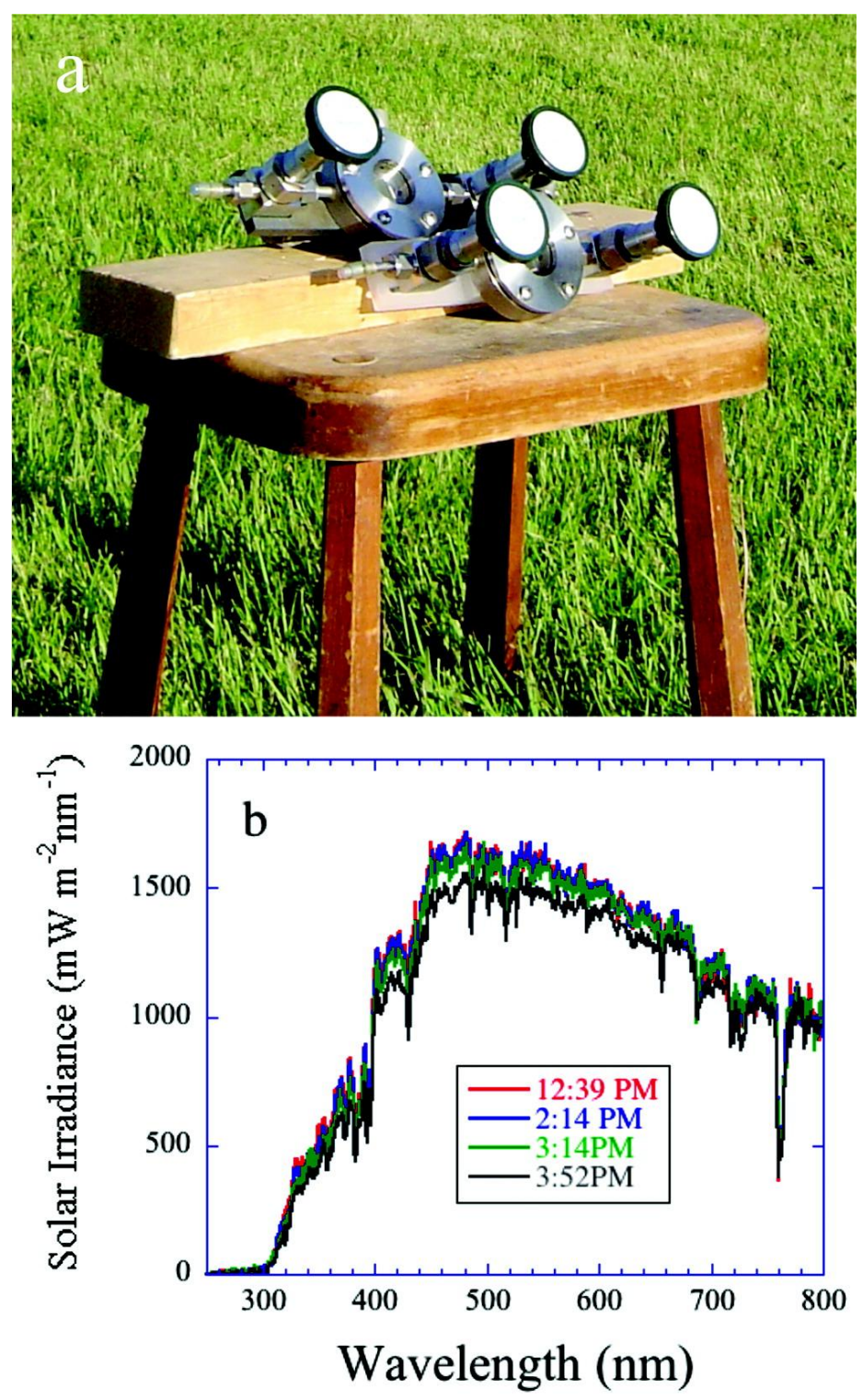
Figure 5.

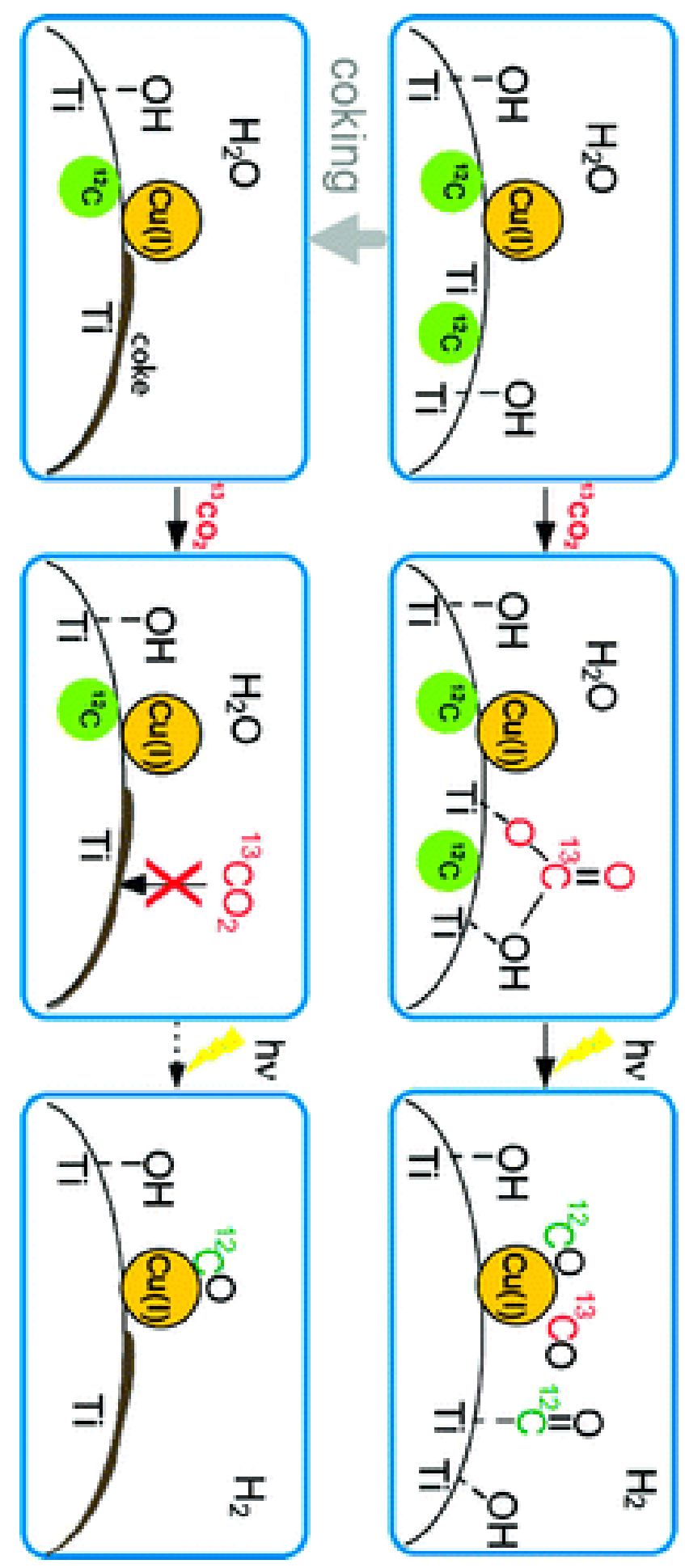


Figure 6.

Product formation rates $\left(\mathrm{nmol} \mathrm{h} \mathrm{h}^{-1} \mathrm{~g}_{\text {cat }}{ }^{-1}\right)$

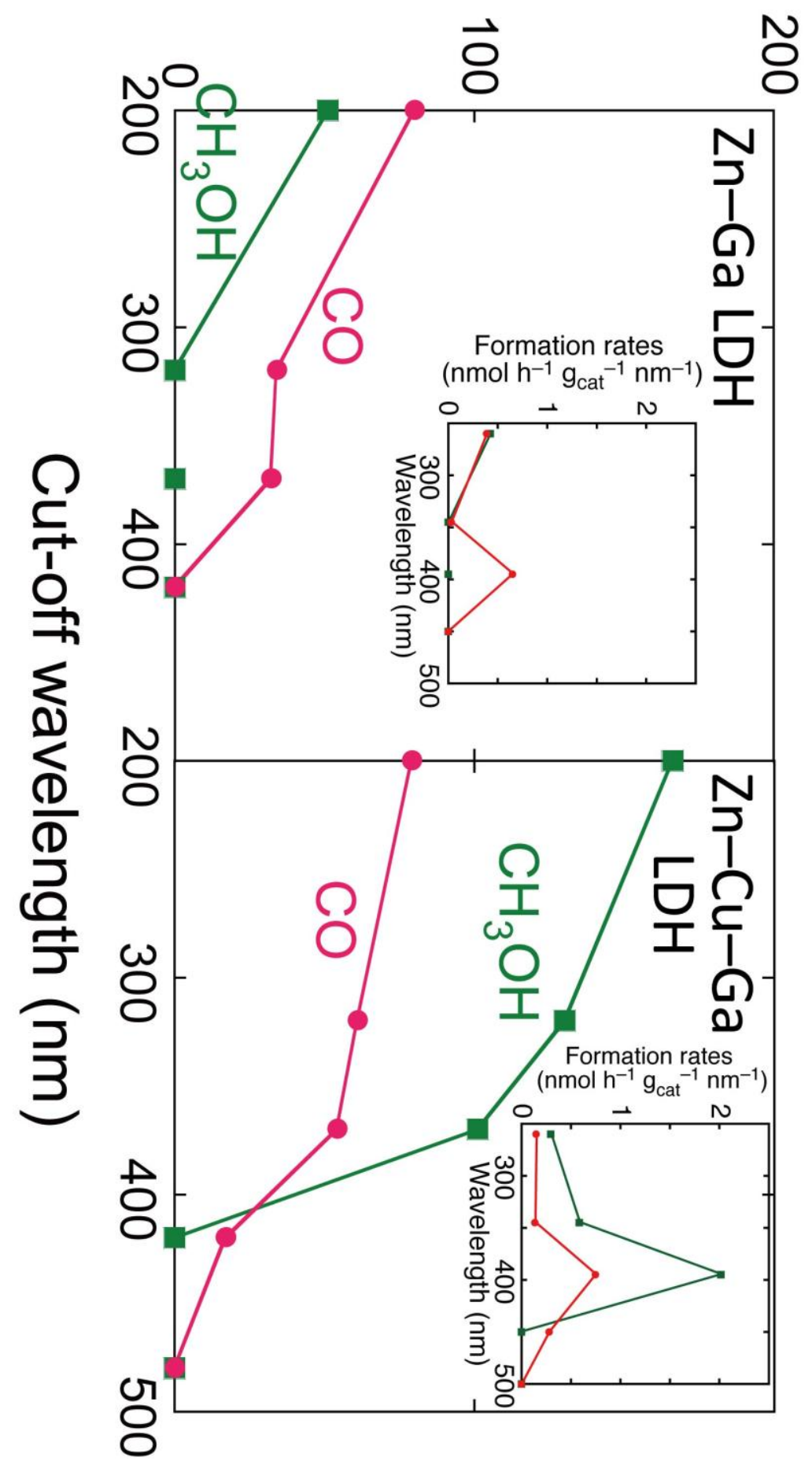


Figure 7.
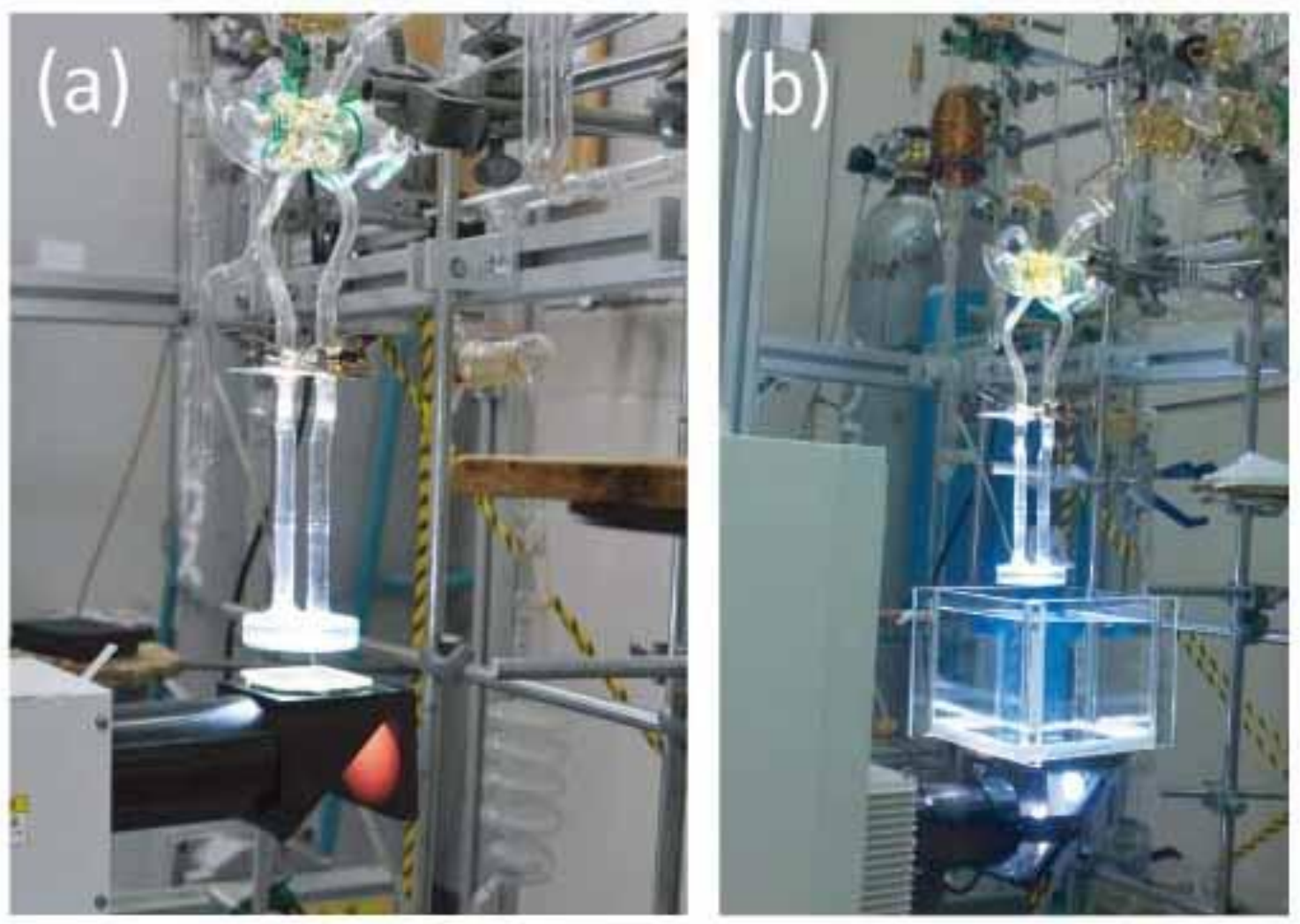
Figure 8.

$\sigma$
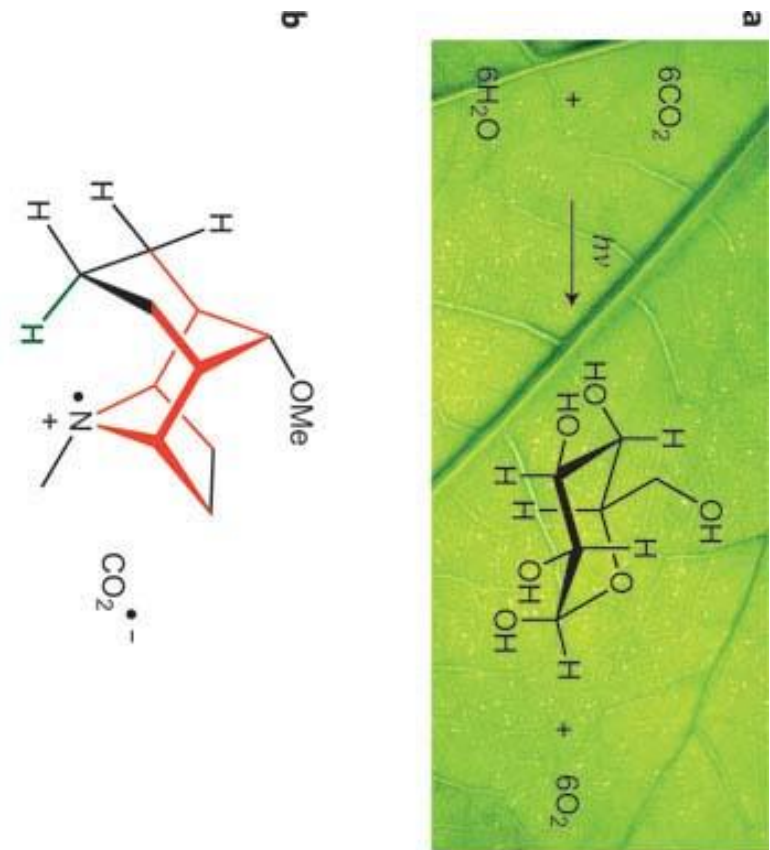

กิ

๑$$
\text { . }
$$ 
Figure 9.

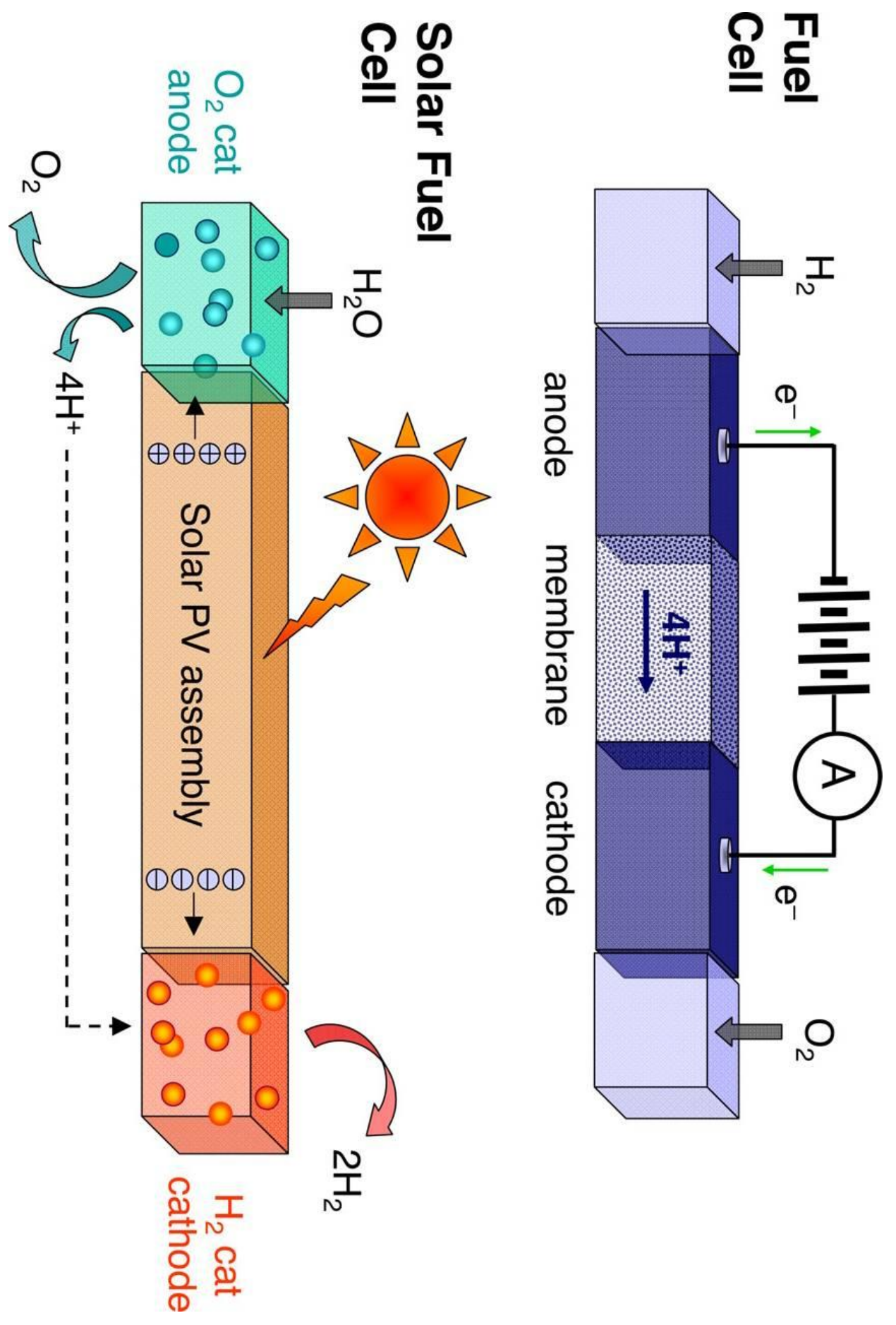


Figure 10.

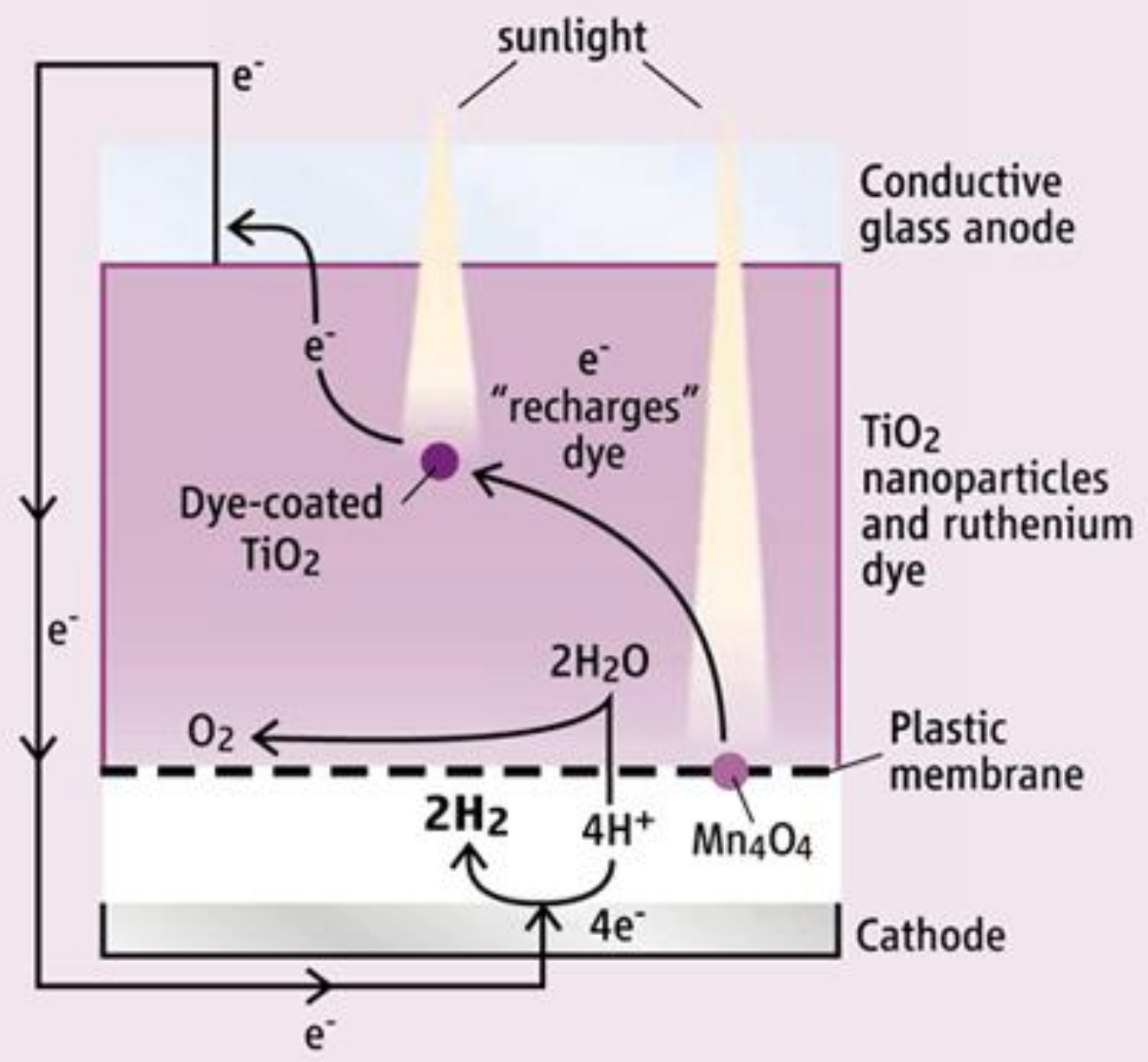


Figure 11.

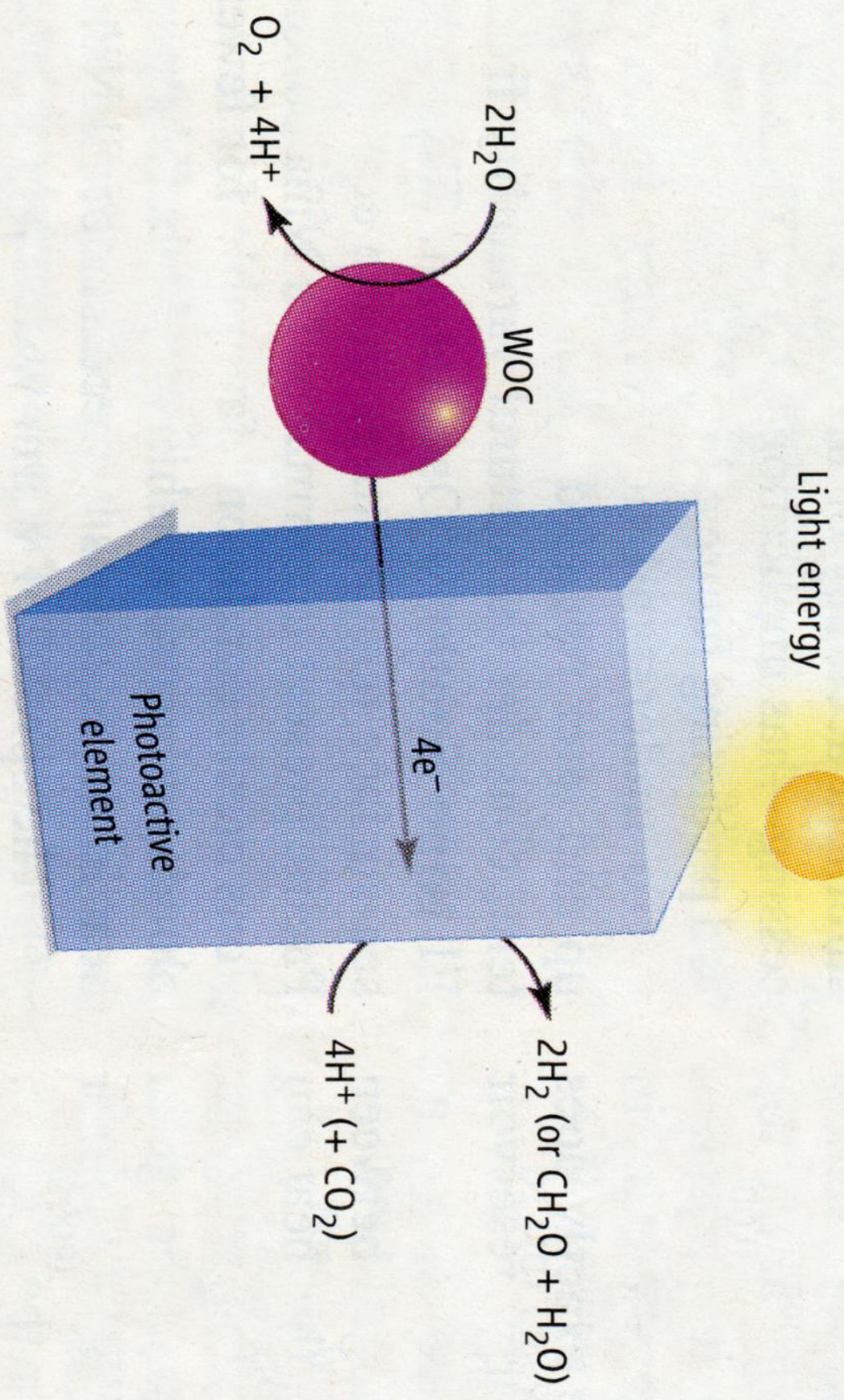


Figure 12.

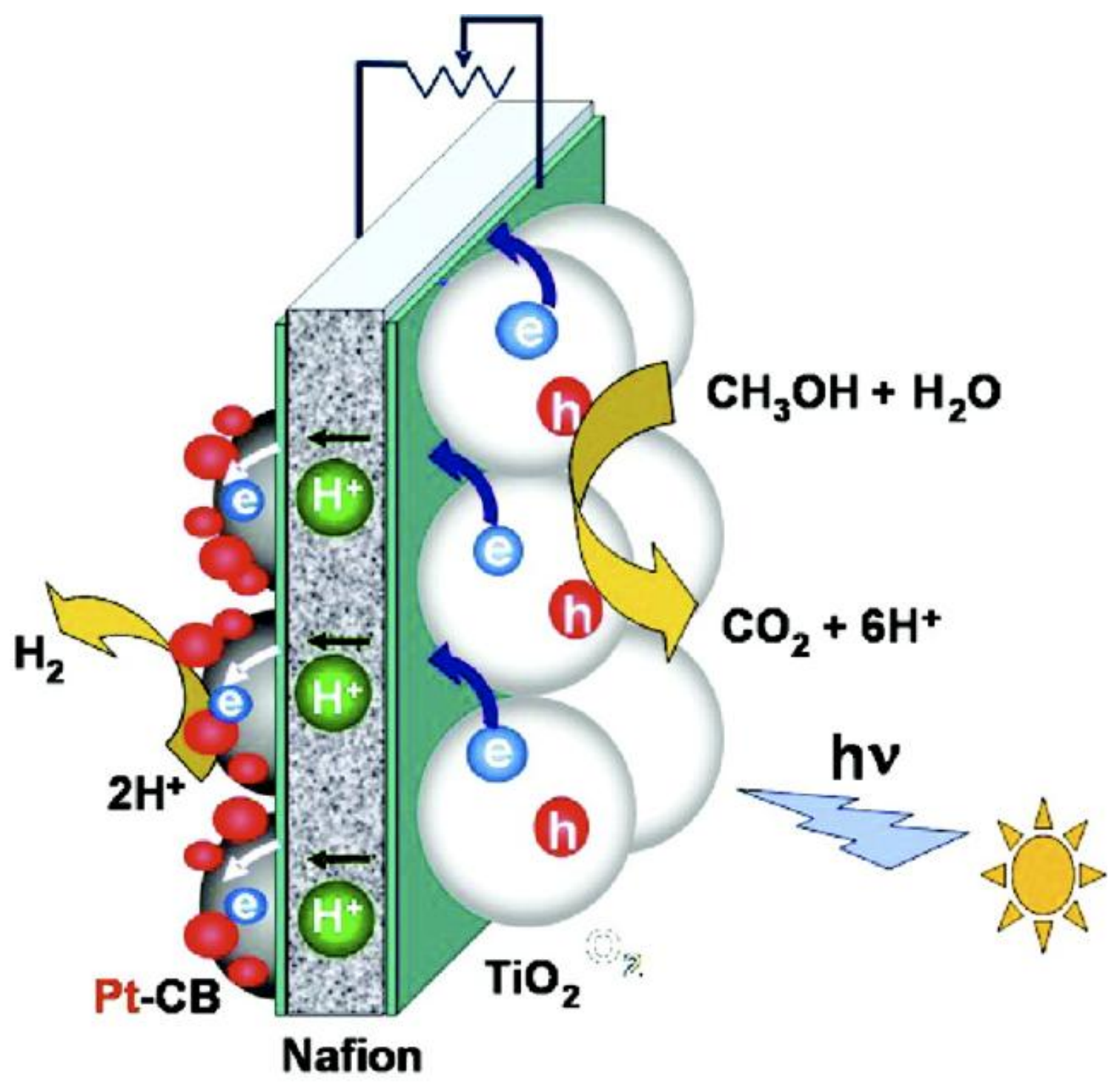


Figure 13.

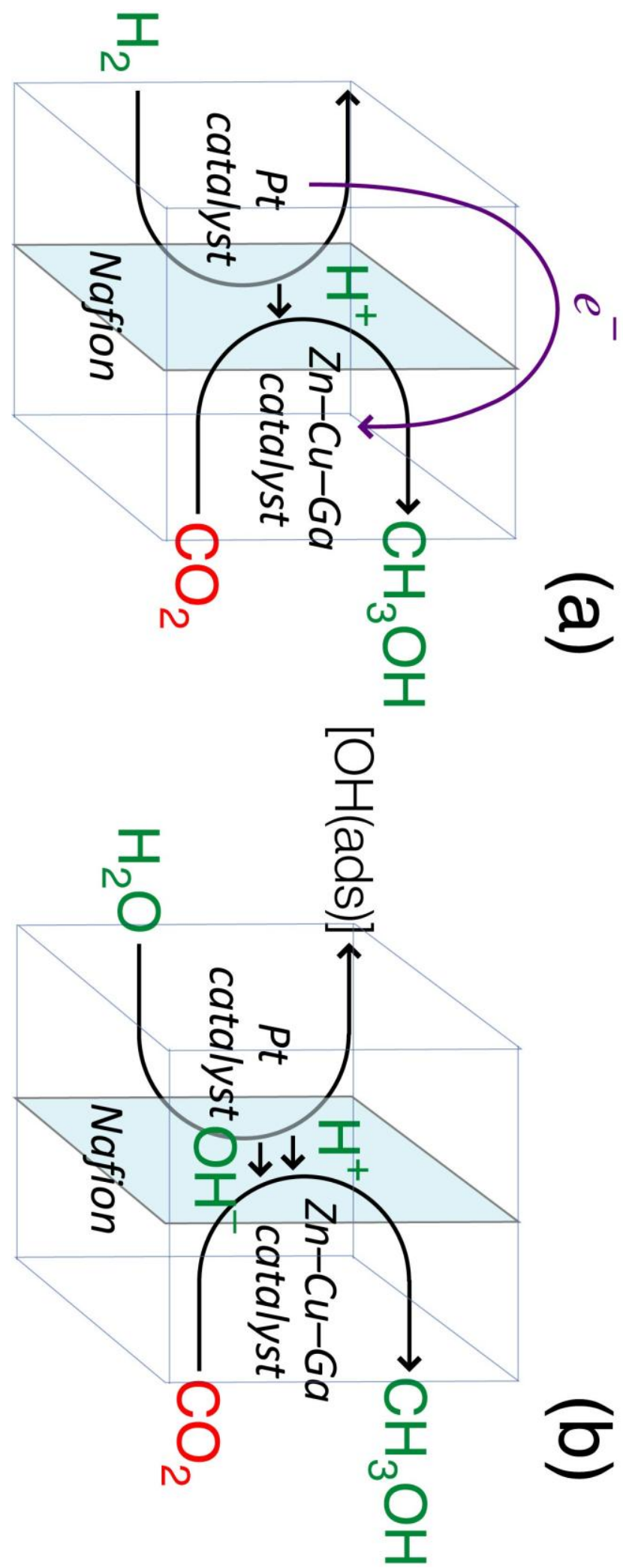

